\title{
Design and impact assessment of watershed investments: An approach based on ecosystem services and boundary work
}

Version 3, July 2016

\begin{abstract}
Watershed investments, whose main aim is to secure water for cities, represent a promising opportunity for large-scale sustainability transitions in the near future. If properly designed, they promote activities in the watershed that enhance ecosystem services while protecting nature and biodiversity, as well as achieving other societal goals. In this paper, we build on the concepts of ecosystem services and boundary work, to develop and test an operative approach for designing and assessing the impact of watershed investments. The approach is structured to facilitate negotiations among stakeholders. Its strategic component includes setting the agenda; defining investment scenarios; and assessing the performance of watershed investments as well as planning for a follow-up. Its technical component concerns data processing; tailoring spatially explicit ecosystem service models; hence their application to design a set of "investment portfolios", generate future land use scenarios, and model impacts on selected ecosystem services. A case study illustrates how the technical component can be developed in a data scarce context in sub-Saharan Africa in a way that is functional to support the steps of the strategic component. The case study addresses soil erosion and water scarcity-related challenges affecting Asmara, a medium-sized city in Eritrea, and considers urban water security and rural poverty alleviation as two illustrative objectives, within a ten-year planning horizon. The case study results consist in spatially explicit data (investment portfolio, land use scenario, impact on ecosystem services), which were aggregated to quantitatively assess the performance of different watershed investments scenarios, in terms of changes in soil erosion control. By addressing stakeholders' concerns of credibility, saliency, and legitimacy, the approach is expected to facilitate negotiation of objectives, definition of scenarios, and assessment of alternative watershed investments, ultimately, to contribute to implementing an adaptive watershed management.
\end{abstract}

KEYWORDS: watershed investment; ecosystem service modelling; boundary work; urban water security; adaptive watershed management; soil erosion control; poverty alleviation; 


\section{Introduction}

Watershed investments (WIs) offer a promising opportunity to effect large-scale transformative changes that promote human wellbeing while protecting life-supporting ecosystems, in the near future (Guerry et al., 2015; McDonald and Shemie, 2014). They consist of governance and financial mechanisms that secure clean water for cities, and operate primarily by engaging upstream communities and nature conservation organizations (Higgins and Zimmerling, 2013). If properly designed, they can guarantee multiple positive outcomes, including enhancement of selected ecosystem services, such as erosion control and nutrient retention, protection of nature and biodiversity, and promotion of other societal goals (e.g. poverty alleviation). Indeed, they can be an effective tool for implementing adaptive watershed management that emerges as a collective effort of stakeholders who engage in iterative learning cycles, to meet an array of objectives (Cortner and Moote, 1994; Gleick, 2000; Pahl-Wostl, 2002; Pahl-Wostl et al., 2011). Their real-life implementation, however, is an arduous challenge that requires "linking diverse sets of actors and knowledge systems across management levels and institutional boundaries" (Kowalski and Jenkins, 2015).

Ecosystem services-related considerations are increasingly included in decision-making (Abson et al., 2014; de Groot et al., 2010; Haase et al., 2014; Maes et al., 2012) and more specifically in impact assessment processes (Geneletti, 2015; Geneletti et al., 2016; Landsberg et al., 2013; Mandle et al., 2015). The concept of ecosystem services, defined as the direct and indirect contributions of ecosystems to human wellbeing (TEEB, 2010), provides a framework for integrating biophysical and socio-economic matters, to address critical planning and management questions. Spatially-explicit modeling of ecosystem services allows generating and exploring future scenarios of watershed management, and optimizing co-benefits, for example by exploiting synergies between ecosystem services (Howe et al., 2014). Examples of spatially-explicit ecosystem service modeling to optimize synergies between economic, social, and environmental objectives can be found in Geneletti (2013), Lawler et al. (2014) and Polasky et al. (2008). In the case of WIs, in particular, ecosystem service modeling translates into spatial terms the consequences of different investment options, putting in direct relation the transformations in the landscape with the spatial distribution of their impacts.

Boundary work, an important tool for WIs, is a promising approach for facilitating knowledge co-production and its collaborative implementation, linking diverse stakeholders. Cash et al. (2003) have originally defined it as a set of measures "put in place by any organization that seeks to mediate between knowledge and action". Recently, Clark and colleagues (2016) proposed a boundary work framework, providing helpful and practical guidance to adopt the most appropriate strategy for each specific context. To our knowledge, their framework is yet to be applied to support an actual process of transfer of knowledge into action, involving WIs.

In this paper, our aim is to support an effective implementation of WIs by jointly exploring the concepts of ecosystem services and boundary work. We here propose an operative approach for designing WIs, and assessing their impact both within and beyond the watershed. The approach defines a set of objectives and related investment scenarios. For each investment scenario, it then applies a relative-ranking method based on the biophysical factors that drive ecosystem services to design investment portfolios. Hence, it generates future land use scenarios that 
represent the implementation of the investment portfolios. Finally, for each future land use scenario, it spatially models the impact on a set of selected ecosystem services, and it uses the results to assess the performance of the investment scenarios as well as to plan for a follow-up.

The aforementioned methodological steps are comparable to those of a typical impact assessment that integrates ecosystem services (Landsberg et al., 2013) and are coherent with an objective-led assessment that aims at maximizing positive social, environmental, and economic outcomes, rather than simply minimizing negative impacts (Bond et al., 2012; Pope et al., 2004, Hacking and Guthrie, 2006). In particular, this study attempts to address an emerging need to "embed resilience thinking into impact assessment; using participatory workshops; and emphasizing adaptive management", as recently suggested by Bond et al. (2015). As they put it, 'business as usual' impact assessment ought to move towards an objectives-led, visioning approach; focus on uncontrollable threats; promote use of analytic-deliberative techniques; focus on embedding resilience in scenarios, and on uncertain events; and recognize the necessity of continual adaptation to changing circumstances. Therefore, in the proposed approach, we emphasize the fact that the design and impact assessment of WIs should involve stakeholders in a dynamic process of co-production of relevant knowledge, and its collaborative implementation. Our approach distinguishes between a "strategic" and "technical" component, thus identifying those aspects that are the most crucial for effectively and timely addressing concerns of different stakeholders, in order to ensure credibility, saliency, and legitimacy (Cash et al., 2003; Clark et al., 2016), throughout the process of interaction, and beyond.

Finally, a case study illustrates how the technical component can be developed in a data scarce context in sub-Saharan Africa in a way that is functional to support the steps of the strategic component identified in the proposed approach. We consider the Toker watershed (TW) and its homonymous reservoir, which are the main water supply for Eritrea's only major city, Asmara. The TW is affected by soil erosion- and water scarcity-related challenges, which hinder the city of Asmara from meeting its growing water needs and, at the same time, exacerbate poverty of rural communities. We assume two illustrative objectives for investments in the TW: urban water security and rural poverty alleviation. The application of the proposed approach to this case study addresses two key questions, reformulated after Vogl et al. (2015) as follows:

i. Which activities, when, and where in the watershed yield the greatest returns, under different investment scenarios?

ii. What is the impact of watershed activities on a selected ecosystem service?

In section 2, we provide the theoretical background of boundary work, specifying its integration in the proposed approach. In section 3, we describe the approach, clarifying the rationale and the boundary work considerations behind each step. In section 4, we present the case study application of the technical component, specifically, answering the two key questions above. In section 5, we discuss the results; finally, in section 6 , we generalize our findings to draw overall conclusions. 


\section{Theoretical background of boundary work}

According to Clark et al. (2016), boundary work, intended as a fundamental tool for WIs, consists of any effort put in place to manage tension that arises at the interface between stakeholders that have differing views on what represents relevant knowledge. Thus, boundary work is an innovative concept that helps understand, and manage the challenges arising from the interactions between stakeholders involved in production and use of knowledge, and its transfer into action (Cash et al., 2003; Clark et al., 2016). Three attributes of boundary work increase the likelihood of its success: participation (i.e. a meaningful participation in agenda setting and knowledge production); accountability (i.e. governance mechanisms to ensure accountability of boundary work put in place); and boundary objects (i.e. collaborative products that are adaptable to different stakeholder perspectives) (Clark et al., 2016; Star and Griesemer, 1989). Three criteria define the effectiveness of boundary work: credibility (i.e. technical adequacy in the handling of scientific evidences); saliency (i.e. relevance to the problem at hand); and legitimacy (i.e. fairness, unbiasedness, and respectfulness of all stakeholders) (Cash et al., 2003; Mitchell et al., 2006). Finally, three functions operatively characterize boundary work: communication (i.e. an active, iterative, and inclusive communication); translation (i.e. translation of concepts to facilitate mutual understanding); and mediation (i.e. mediation to resolve potential conflicts) (Cash et al., 2003; Clark et al., 2016).

Boundary work is a dynamic process that has to address diverse types of "tension" at the interface between stakeholders (Parker and Crona, 2012); it thus needs to consider the embedding socio-ecological system, accounting for its contextual (i.e. relatively stable) and contingent (i.e. relatively changeable) factors as well as the relative influence of the involved social actors. Applied to WIs, this means it is important to gain a good understanding of the embedding socio-ecological context, exploring the roles and possible interaction between the stakeholders, to determine the boundary work needed to achieve a theoretical potential, and gain an optimal transfer of knowledge into action. Thus, the need to define timely measures of participation and accountability, and to highlight boundary objects that could be realized during the process of WIs design and assessment, specifying appropriate strategies of communication, translation, and mediation to be deployed. In the light of the considerations above, and given that stakeholders have differing concerns of credibility, saliency, and legitimacy, the overall effectiveness of boundary work should be seen as an emergent outcome of this dynamic process.

\section{An operative approach for the design and impact assessment of WIs}

In this section, based on the boundary work considerations above, we tailor and propose an operative approach for the design and assessment of WIs. Taking into account the different stakeholders concerns and related boundary work needs, the approach distinguishes between a strategic component (mainly addressing saliency and legitimacy) and a technical component (mainly addressing credibility) (Figure 1). Each component is divided into an initial, intermediate, and final stage, which reflects the dynamic nature of boundary work and the important role of timing. The three stages of the strategic component include setting the agenda (Section 3.1), defining investment scenarios (Section 3.2), and assessing their performance to 
then plan for a follow-up (Section 3.3). While for the technical component, they consist of biophysical data processing (Section 3.4), tailoring of spatially explicit ecosystem service models (Section 3.5), followed by their application to generate investment portfolios and land use scenarios, and to model the impacts on a set of selected ecosystem service (Section 3.6).

In the remainder, we describe the three stages of the strategic component, first, and those of the technical component, then; for each stage, we clarify the rationale and the boundary work considerations behind.it.

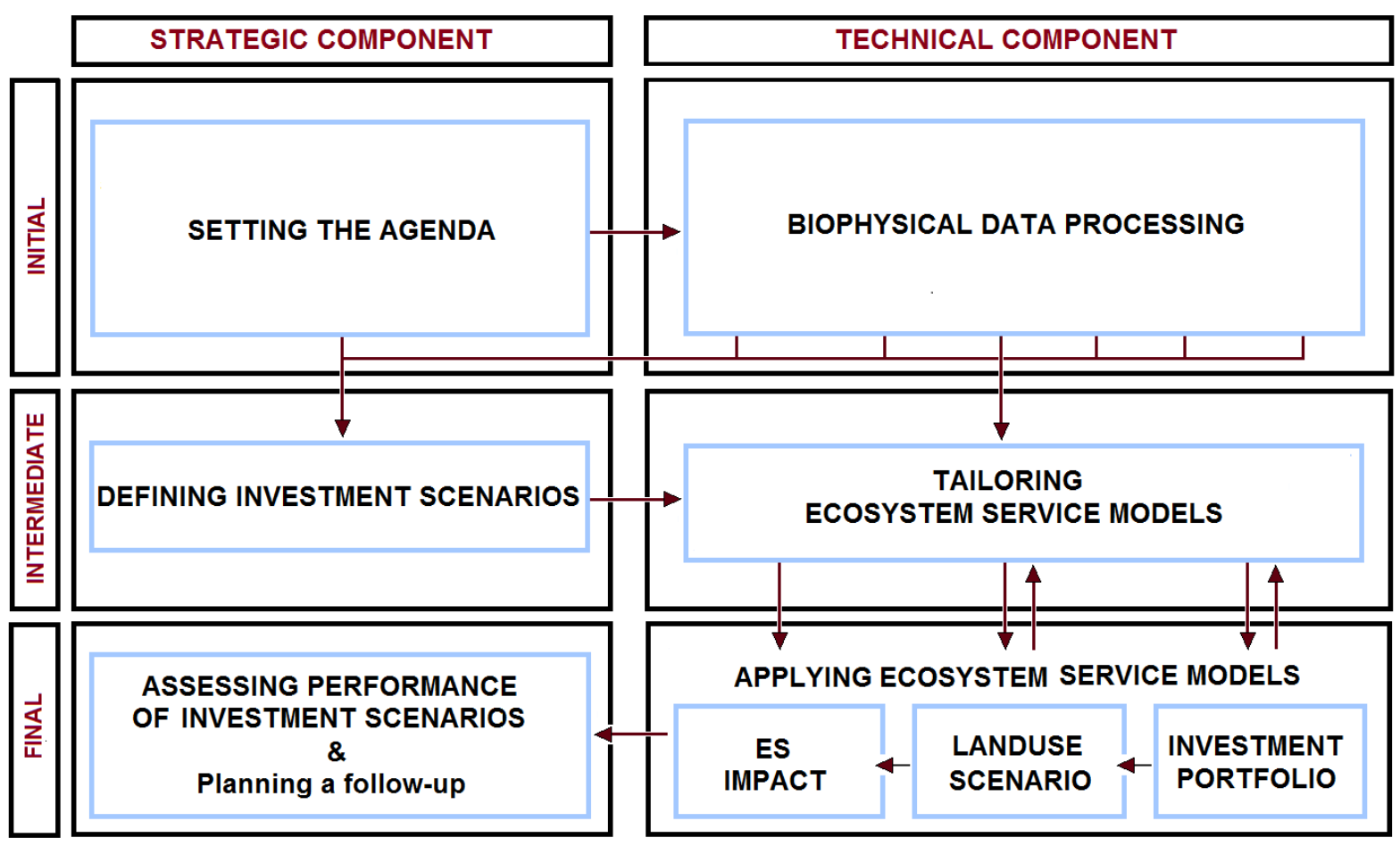

Figure 1: The operative approach for designing and assessing WIs

\subsection{Setting the agenda}

This initial stage requires a deep understanding of the socio-ecological context in which the proposed approach is to be applied, including the contextual and contingent factors, and the relative influence of the social actors. From a boundary work perspective, joint agenda setting can help achieve saliency and legitimacy, and thus contribute to building an "an arena for knowledge coproduction, trust building, sense making, learning, vertical and horizontal collaboration, and conflict resolution" (Berkes, 2009). In fact, an agenda jointly set by the stakeholders can be a first important boundary object of the process of WI design and assessment. In our approach, setting the agenda consists of the following four steps.

Defining investment objectives and planning horizon, identifying, and prioritizing ecosystem services. Numerous factors contribute to defining WI objectives and related planning horizon, including legal limitation and standards, empirical evidences, stakeholders' negotiations, and 
experts' opinion (Vogl et al., 2015). This is followed by the identification of the most relevant ecosystem services, hence the prioritization and selection of some for more in-depth analyses (i.e. WIs design and impact assessment), as for example suggested in Landsberg et al. (2013) and in Geneletti (2015). What is important is that defining WIs objectives, identifying, and prioritizing related ecosystem services provide a good opportunity for enhancing both saliency and legitimacy, by involving as much as needed the different stakeholders.

Characterizing stakeholders. A promising concept useful to identify and characterize stakeholders is that of "service-sheds" (Tallis et al., 2015). It consists in ideally "tracking" the flow of ecosystem services that benefit a particular group of people, hence delimitating the geographic areas of production of such ecosystem services. Service-sheds can be an effective tool for highlighting key societal issues such as the spatial mismatch between areas of ecosystem service production and benefit, sharing of costs for maintaining ecosystems services, and more generally addressing challenges of inter and intra-generational equity (Lamorgese and Geneletti, 2015). However, tracking flow of ecosystem services can be quite cumbersome (Pagella and Sinclair, 2014); especially when considering the different ways in which groups of people with different socio-economic conditions benefit from ecosystem services (Daw et al., 2011). Moreover, in the case of WIs, there is need to distinguish between "losers" and "winners". The former, comprise those negatively affected by activities undertaken within the WI (e.g. farmers losing access to protected areas or introducing new agricultural practices). The latter include those whose wellbeing the WI considers as a target (e.g. people in cities benefiting from more water or rural communities involved in poverty alleviation initiatives). However, the two categories are not mutually exclusive, such as the case of rural communities that lose access to protected area, but at the same time, benefit from poverty alleviations measures. Therefore, defining, in a more detailed way, "who is who" and their role in the stakeholders' negotiation is left as an empirical question for the actual application of the here proposed approach. In turn, this determines the type of boundary work that needs to be put in place, in order to address the concerns of saliency and legitimacy of the different stakeholders.

Budgeting watershed investments. Generally, it is an outcome of complex societal negotiations. Instead, we here propose a relatively simple approach, which consists in estimating the value of ecosystem services, by adopting the perspective of a given stakeholder (e.g. loss of storage capacity due to soil erosion, which negatively affects a water utility). To an extent, this choice also accounts for a general tendency of stakeholders to strongly prefer avoiding losses to acquiring gains, the so-called "loss aversion" bias (Kahneman and Tversky, 1984). A good working example is the renowned case of New York City and the Catskills-Delaware watersheds in which the issue of budgeting was strongly and favorably affected by the adoption of an ecosystem service perspective (Turner and Daily, 2008).

Selecting watershed activities. This step requires good contextual knowledge and substantial input from the different stakeholders, all very important for identifying the activities, specifying their effectiveness, and determining their unitary costs. The selected activities need to be adequately characterized in order to determine their potential contribution in meeting WI objectives, and this should take into account the preference of the different stakeholders. In fact, 
activities may diversely involve and affect different stakeholders; for example, measures taken to protect natural areas could limit access to local communities, on the other hand, improvement of agricultural vegetation management could increase crop yield. Therefore, the process of selection and characterization of activities can be an important way of fostering a "meaningful communication" among stakeholders, thus contributing to ensure both saliency and legitimacy.

\subsection{Defining investment scenarios}

For a given agenda, defining investment scenarios aims at addressing key questions, such as "how does budget level affect the outcomes of WIs?", "what is the most cost-effective combination of activities, for a given budget?", and "what if the whole budget is allocated to a single activity?" and so on. In the proposed approach, scenarios are defined based on three elements, namely, WI objective, budget level, and budget allocation modality. Two budget allocation modalities are considered: one based on cost-effectiveness of activities, and one in which the entire budget is pre-allocated to a single activity at a time. Above all, investment scenarios need to be discriminated based of their desirability and/or feasibility, through a meaningful participation of stakeholders. From a boundary work perspective, jointly defining, and discriminating investment scenarios allows further addressing the concerns of saliency and legitimacy of different stakeholders, also benefiting from their previous interactions in the initial stages of both the strategic and technical components.

\subsection{Assessing the performance of investment scenarios and planning a follow-up}

The last stage of the strategic component deals with comparing the performance of different investment scenarios, based on the findings of the technical component (Section 3.6) and taking into account the feasibility, and desirability of scenarios expressed by the different stakeholders (Section 3.2). Ultimately, it aims at selecting, in a possibly participatory fashion, the actual WI to be implemented on the ground; hence, at planning for a follow-up that covers the entire planning horizon. The performance of each investment scenario can be assessed in terms of the change occurring in selected ecosystem services, expressed in their biophysical, social or economic values, with respect to the baseline conditions. These aggregated performance values are also supported by spatially and temporally explicit data from the technical component. Such data, besides providing detailed guidance on how to implement the selected WI (which activity, where and when), also forms the basis for planning a follow-up (i.e. monitoring, evaluation, management, and communication), which is a crucial yet often overlooked phase in the impact assessment practice (Morrison-Saunders et al., 2007). Boundary work wise, the last stage of the strategic component has to ensure saliency and legitimacy towards the different stakeholders, building on the scientific credibility of the findings of the technical component. This is a challenging task because, at times, stakeholders' interests and needs can be simply incommensurable (Parker and Crona, 2012), and its success is determined by the extent to which credibility, saliency, and legitimacy concerns have been effectively and timely addressed in all the previous stages. 


\subsection{Biophysical data processing}

The initial stage of the technical component deals with analyzing the need and the processing of biophysical data related to the WIs objectives. It is thus entirely dependent on the identification and prioritization of key ecosystem services in the strategic component. These are the ecosystem services considered for spatially explicit modeling, to support the WIs design and assessment. The type of biophysical data and its processing is highly linked to the specific ecosystem services; thus, we leave the description to the case study application. From a boundary work perspective, this stage plays a significant role in ensuring scientific credibility of the proposed approach and its outputs, by providing opportunities for linking expert and stakeholders' knowledge. For example, data and resource scarcity, which are perhaps the main challenges, at this stage, they could trigger meaningful communication between stakeholders and experts, concerning data collection campaigns, selection of modeling tools, and complexity and uncertainty of models, among others.

\subsection{Tailoring ecosystem service models}

At the core of the here proposed approach, there are two software tools based on ecosystem services: RIOS (Vogl et al., 2015) and InVEST (Sharp et al., 2015). Both the tools have been developed by the Natural Capital Project during an over a decade long transdisciplinary research, carried out involving real-life stakeholders in WIs. From a boundary work perspective, the tools, approaches, and lessons learned by such transdisciplinary project (e.g. Ruckelshaus et al., 2015) underpin the scientific credibility of our approach for WI design and impact assessment. RIOS stands for "Resource Investment Optimization System"; it allows targeting watershed investments, based on stakeholders' ecosystem service objectives, their preferences about where activities may occur, and the amount of money that is available for implementing the activities (Vogl et al., 2015). RIOS applies a relative-ranking approach, considering important biophysical factors that drive the ecosystem service (Vogl et al., 2015); and is used for designing investment portfolios, where the most cost-effective locations for activities are provided, and generating future land use scenarios. InVEST is a suite of spatially explicit ecosystem service modeling tools that quantify service provision (Sharp et al., 2015). In the proposed approach, InVEST is used to model the impacts on purposely selected ecosystem services, based on the results of RIOS (See Part I of the Supplementary material).

Figure 2 summarizes the rationale behind the RIOS approach described in Vogl et al. (2015). Accordingly, WIs target directly a range of activities (now), to trigger a relatively finite set of changes in the watershed, ultimately causing a desired transition in the land use and management (in the future). Such transitions affect many of the processes that regulate hydrologic processes and biodiversity, such as water infiltration rates, soil storage capacity, vegetation cover and structure as well as the maintenance of habitat quality and feeding and breeding resources for species (Vogl et al., 2015). Ultimately, they affect the future land use and related ecosystem services, thus contributing to meeting specific WI objectives. 


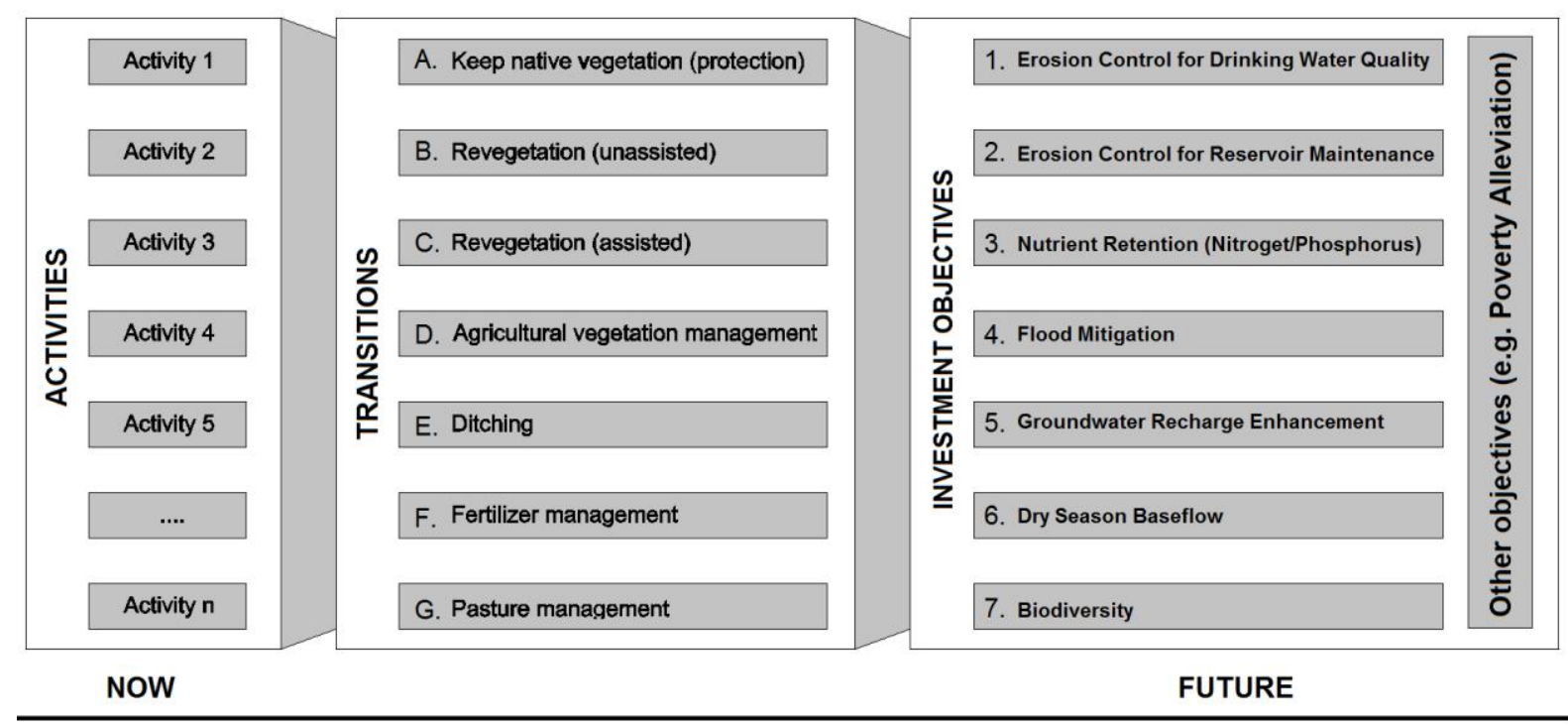

Figure 2: Rationale behind the RIOS approach: Investing in Watershed Activities now to trigger Transition, thus meet WI objectives in the future (based on Vogl et al. 2015)

Technically, RIOS supports any type of activity at landscape-level, but it does not include grey infrastructure solutions such as check dams and retaining walls. Moreover, each activity must map to one of seven supported transitions, shown in Figure 2. Namely, keeping native vegetation (retaining vegetation likely be lost); assisted or unassisted revegetation (revitalizing vegetation on degraded lands with or without out active interventions); agricultural vegetation management (increasing crop structure, coverage and/or diversity); ditching (improving infiltration and slowing sediment and nutrients transport); fertilizer management (changing fertilizer application); and pasture management (changing management practices). Likewise, RIOS supports seven ecosystem service-related objectives, shown in Figure 2, with possibility of including other objectives, such as poverty alleviation, defined by the user outside of RIOS.

In the RIOS approach, critical inputs include the so-called "transition potentials" (i.e. which "activities" cause which "transitions"), the "objective-transition weights" (i.e. relative contribution of each transition to the objective of the WI), and the "unit cost" of each watershed activity. Other important inputs are additional restrictions on watershed activities related, for example, to land use and land cover (LULC), slope, or elevation. A full description of the ecosystem service models, including information on their assumptions and limitations, and data pre-processing can be found in Sharp et al. (2015) and Vogl et al. (2015). In Part I of the Supplementary Material, based on Vogl et al. (2015), we provide a description for non-experts of the type of data that is needed, and how it is analyzed to design the investment portfolio. From a boundary work perspective, this can be a good example of "translation of concepts to facilitate mutual understanding", aiming at ensuring credibility in the eyes of the stakeholders.

\subsection{Applying ecosystem service models}

Designing investment portfolio. For each scenarios, the RIOS module "Investment Portfolio Advisor" is applied to combine the biophysical and socio-economic input data from the sections 
above in order to design a set of investment portfolios. An investment portfolio consists of a spatially, and temporally explicit allocation of the overall budget between the watershed activities. For a given scenario (i.e. WI objective, budget level, budget allocation modality), it defines which activities, when during the planning horizon, and where in the watershed are the most cost effective.

Generating future land use scenarios. For each investment portfolio, the RIOS module "Portfolio Translator" is applied to generate land use scenarios that are related to the watershed activities. They represent the future condition of the watershed, where RIOS-selected activities are implemented and embedded into the map of land use and land cover (LULC). Operatively, for each existing LULC type, we specify the new LULC, which would result from a specific transition. It is worth noticing that some transitions (e.g. assisted revegetation) imply an actual land use change, while others (e.g. ditching) result in a change of the biophysical parameters that affect the ecosystem service of interest (e.g. in the case of soil erosion control, such biophysical parameter include sediment retention, sediment export, USLE crop factor).

An additional RIOS parameter, used to generate future land use, is the "Proportional Transition Factor-PTF". With a value between 0 and 1, the PTF specifies what proportion of the baseline LULC is likely to be transitioned to the new LULC at the end of the planning horizon. Indeed, defining the PTF, which is an important parameter that is tightly linked to the socio-ecological system of interest, provides a good opportunity for incorporating local knowledge, and thus underpin the credibility of the process.

Modelling impact on selected ecosystem services. The last stage of the technical component deals with modeling the impacts on a set of selected ecosystem services, using InVEST. The RIOS-generated future land use scenarios and biophysical parameters, all provided in a format that can be directly imported in InVEST, represent the input data. In the case study application, for example, the impact on soil erosion control was modeled. The seven sub-watershed in the TW were used as spatial units of analysis and service-sheds. For each scenario, soil erosion per unit area in hectares was evaluated at sub-watershed level, and the percentage change was calculated with respect to the baseline conditions, defined by the existing land use and the respective biophysical parameters. This percentage change information is the same used in the last stage of the strategic component, to assess the performance of WIs; therefore, closing a first round of the dynamic process of negotiation among stakeholders involved in knowledge use and production in WIs design and assessment.

\section{Case study application of the technical component}

In this section, our aim is to test the above-described technical component in a data scarce context. Thus, we purposely put little attention on the strategic component, which is only based on a review of documents and interviews with key informants, and mainly serves to set a reallife socio-ecological background. The ultimate goal, however, is to highlight the potential of the proposed approach to support a process of stakeholder negotiations for WIs design and 
impact assessment. To this end, we here present some illustrative outputs allowing to answer the original two research questions: (i) which activities, when, and where yield the greatest returns?, and (ii) what is the impact on a selected ecosystem service?

In the remainder, we first introduce the baseline conditions in the TW (Section 4.1). We then present the first two stages of the strategic component: setting the agenda (Section 4.2) and defining investment scenarios (Section 4.3). Hence, we for the technical component, we report some illustrative results concerning biophysical data processing; investment portfolios; and impact on soil erosion control (Sections 4.4 and 4.5). Finally, we present the results for the last stage of the strategic component, dealing with assessing the performance of investment scenarios and planning for a follow-up (section 4.6). In Part III of the Supplementary Material, we provide additional results, including two tables that synthesize the investment portfolios in the case study, and a third table that shows the performances of WIs at sub-watershed level.

\subsection{Baseline conditions in the Toker Watershed (Eritrea)}

As shown in Figure 3, the TW is the main water supply for Eritrea's capital city, Asmara, which is located in the most densely inhabited region, The Central Region, and accounts roughly for 10 percent of the total population. Figure 4, which illustrates the distribution of land use and land cover (LULC), based on a simplified classification adopted by the RIOS approach (Vogl et al., 2015), is representative of the baseline condition in the TW. It also shows the reservoirs and sub-watersheds in the TW, which are used as, respectively, entry points and spatial units for our case study analysis.

In the TW, soil erosion and water scarcity, two complex socio-ecological challenges, emerge among the most critical issues that require urgent action. Soil erosion is caused by a long history of poor cultivation and overgrazing, unregulated wood and timber harvesting, lack of recycling of nutrients and poor management of organic matter, as well as rapid urbanization and demographic growth (Niaz Murtaza, 1998; Tewolde and Cabral, 2011). Water scarcity is mainly due to persistent droughts also associated with climate variability and change (Abraham et al., 2009; IPCC, 2014; MoLWE, 2012). Overtime, to face physical water scarcity, several reservoirs have been built to store surface water, during two wet seasons known as "kiremti" (June-September) and "asmera" (March-April). These reservoirs are the main sources of water for meeting urban and rural demands, including irrigation, livestock watering, domestic water supply, and other uses. Soil erosion however is rapidly decreasing their storage capacity, further compounding physical water scarcity with economic water scarcity (Abraham et al., 2009).

From a boundary work perspective, reaching consensus over the baseline conditions (e.g. prioritizing socio-ecological challenges, agreeing on the LULC distribution, or adopting subwatershed instead of other administrative boundaries as units of analysis) can be a good example of a boundary object. As such, it requires adequate participation of key stakeholders (e.g. local authorities, experts, and farmer representatives) and accountability measures (e.g. legal role of water utilities to manage watersheds), to jointly ensure saliency, legitimacy, and in part credibility. Equally important is creating meaningful communication among stakeholders, translating concepts to make them accessible to laypersons, and mediating possible conflicts (see RIOS description in Part I of the Supplementary material). 

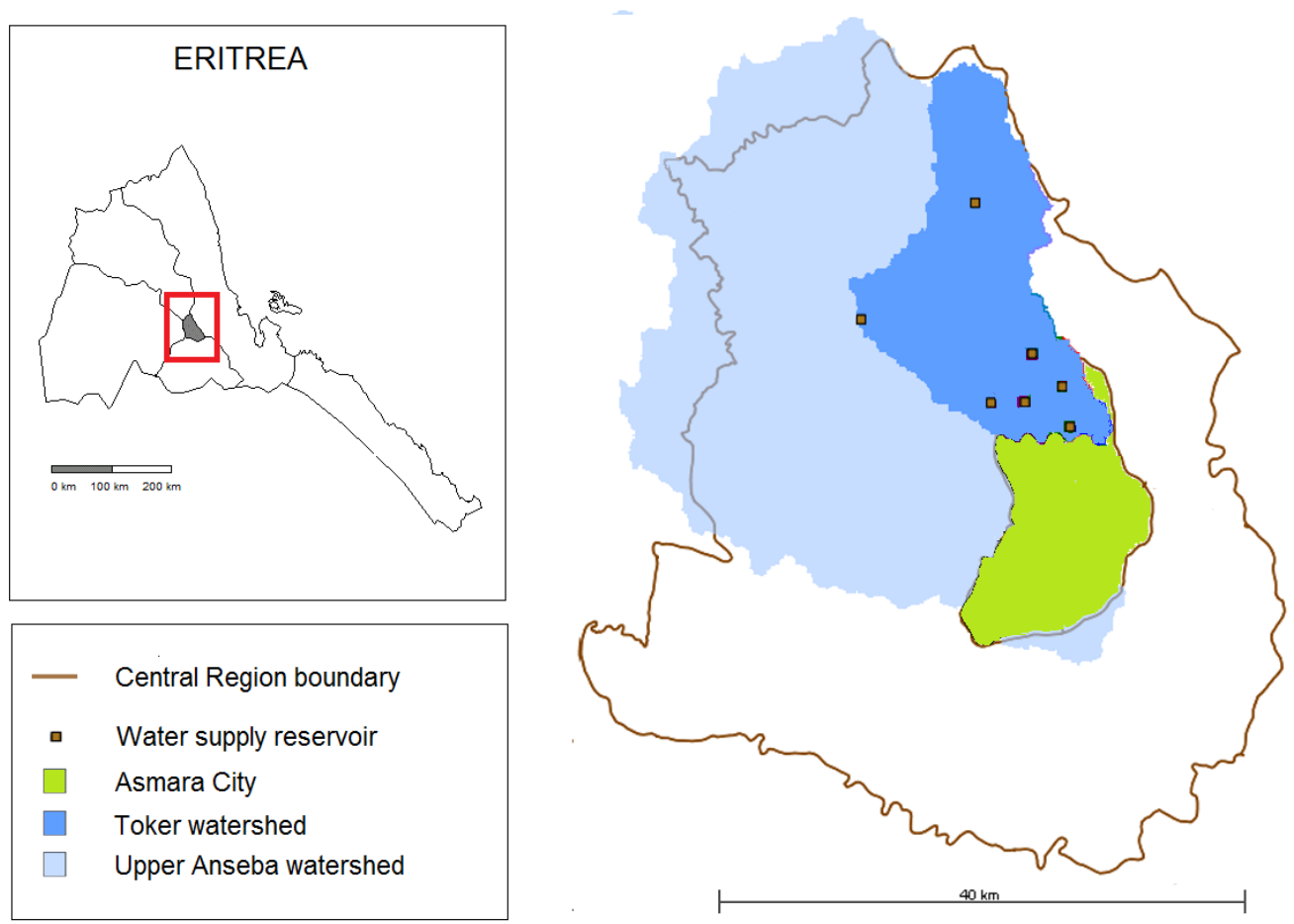

Figure 3: The six administrative regions in Eritrea based on the main watersheds; the Central Region, the smallest and most densely inhabited in the country (left). The Toker watershed, a sub-watershed of the Upper Anseba, located in the Central Region, and the seven reservoirs that supply water to Asmara (right).

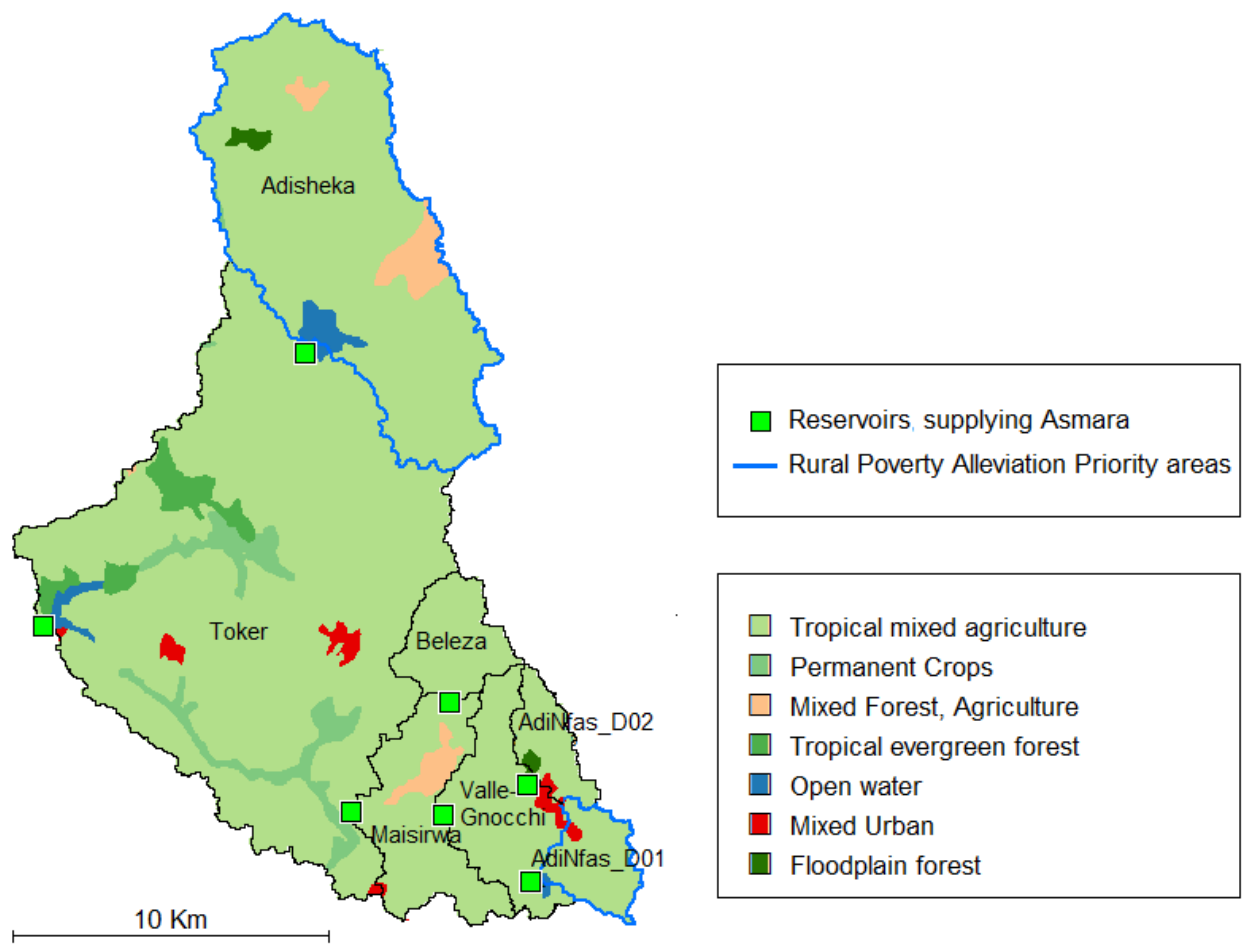

Figure 4: Land use in the Toker watershed and location of the seven reservoirs and sub-watersheds that supply water to Asmara. Land use classes are based on a simplified RIOS classification described in Vogl et al. (2015).

Highlight of the rural poverty alleviations priority areas, i.e. AdiSheka (north) and AdiNfas_D01 (south). 


\subsection{Setting the agenda}

Soil erosion and water scarcity diversely affect different groups of people in the TW. The former causes a rapid loss of storage capacity of reservoirs supplying the city of Asmara. According to Abraham et al., (2009), the estimated average sediment yields in the region is of $856 \mathrm{t} / \mathrm{Km} 2$, corresponding to an annual storage capacity loss of $0.5-2$ percent. Soil erosion also affects livelihood of rural communities by lowering yields; the Food and Agriculture Organization has estimated that an annual rate of soil erosion of $1500 \mathrm{t} / \mathrm{Km}^{2}$ reduces yields by 0.2-0.4\% for crops and 0.05-0.1\% for livestock (FAO 1994, as cited in Habtetsion and Tsighe, 2007). As for water scarcity, based on a study by Abraham et al. (2009), the total number of reservoirs in the Upper Anseba Watershed is 49, of which the 11 biggest ones supply water to Asmara, and 38 smaller reservoirs serve rural communities for drinking and irrigation purposes (Abraham et al., 2009). Of the 11 reservoirs in the Upper Anseba Watershed, 7 are located within the TW. The aggregated storage capacity of the 49 reservoirs is 32 million cubic meters, and 24.8 million $\mathrm{m}^{3}(77.4 \%)$ is reserved for Asmara. Yet, due to siltation, only 55-89\% of that storage capacity is estimated to be actually still available (Abraham et al., 2009).

Therefore, soil erosion and water scarcity hinder the city of Asmara from meeting its growing water demands at the same time seriously jeopardize the main sources of income of the rural communities, whose livelihood depends primarily on rainfed agriculture.

Defining and operationalizing investment objectives. Two illustrative WI objectives, i.e. urban water security and rural poverty alleviation, and a ten-year planning horizon were assumed. Accordingly, and by way of example, soil erosion control was considered as the most relevant ecosystem service, to be used for the WIs design and assessment. For the first WI objective, aiming at decreasing sediment yield to reservoirs, RIOS was applied to design investment portfolios. Likewise, RIOS was applied for the second WI objective; yet, spatial constraints that define investment priority areas were added. These are areas of the watershed where activities are to be preferred or avoided irrespective of their cost-effectiveness. In the TW case study, activities in the AdiSheka and AdiNifas_D01 sub-watersheds were prioritized (see Figure 4), assuming rural communities could benefit from WIs both in terms of poverty reduction (e.g. financial resources that integrate their livelihood in exchange of maintenance of ecosystem services) and poverty prevention (e.g. erosion control that increases crop and livestock yield).

Characterizing stakeholders. In the TW case study, given the focus on soil erosion control, watersheds represent the actual service-sheds. Therefore, reservoirs and their sub-watersheds were used, respectively, as entry points for identifying who utilizes the reservoirs and spatial units for exploring the linkages between ecosystem services, activities, and different groups of stakeholders. Operatively, the TW was divided into seven sub-watersheds, corresponding to seven reservoirs that supply the city of Asmara. The beneficiaries were divided in urban (inhabitants of Asmara) and rural (213 and 300 rural households, benefiting from AdiSheka and AdiNifas_D01 reservoirs respectively). Moreover, urban and rural beneficiaries were reasonably assumed to be uniformly distributed over the city area and the sub-watershed of interest, respectively. At this stage, this can be an acceptable approximation, given the focus on 
the urban-rural divide, and not on the differentiated access to benefits within the city itself. Finally, collecting new socio-economic and demographic data was beyond the scope of this study, thus previous surveys were relied on (e.g. Abraham et al., 2009).

Budgeting watershed investments. The water utility and the inhabitants of Asmara, almost entirely reliant on the TW, were assumed the most influential, and the most affected stakeholders. Thus, the cost of soil erosion was estimated in terms of the depreciation of asset value. Considering a value of US\$44 million for Toker Dam alone, an annual storage capacity loss of 0.5-2\% (Abraham et al., 2009) would translate in a reduction of asset value of \$220$\$ 880$ thousands per year. This is a rough but important estimate, which can be used as a scienceinformed evidence both for budgeting WIs and, more strategically, advocating the relevance of WIs in the TW.

Selecting watershed activities. By way of example, four relevant activities were selected, mainly based on ongoing initiatives in the TW. They include: (i) Restoration through assisted revegetation, where native trees are planted in degraded areas (restoration); (ii) Protection of native vegetation, to limit deforestation (protection); (iii) Terracing, to reduce erosion in steep areas and (iv) Agricultural vegetation management, involving farmers in erosion control measures through voluntary agreements (agricultural vegetation management).

\subsection{Defining investment scenarios}

Following the budgetary consideration in section 4.2, to cover different stakeholders' level of willingness to invest, six annual budget levels were considered: $\$ 10.000, \$ 50.000, \$ 100.000$, $\$ 250.000, \$ 500.000$, and $\$ 1.000 .000$. For budget allocation between activities, two different modalities were applied: cost-effectiveness of activities; and pre-allocation of the entire budget to a single activity at a time. The total number of scenarios can be expressed as $(1+n) * m * k$, where $\mathrm{n}, \mathrm{m}$, and $\mathrm{k}$ are the number of activities, budget levels, and objectives, respectively. In the case study, we thus considered 60 possible scenarios, given by $(1+4) \times 6 \times 2$. At this stage, however, the characterization of the different scenarios based on their feasibility and/or desirability by the stakeholders was not included.

\subsection{Biophysical data processing}

In the TW case study, both the investment objectives are related to soil erosion. Therefore, based on the methods that are implemented in RIOS, the needed input data are: land use and land cover (LULC), digital elevation model (DEM), rainfall erosivity, soil erodibility, soil depth, USLE C factor, and landscape factor (Vogl et al., 2015). Owing to lack of local data, however, some of these input data were obtained from online databases, such as the Harmonized World Soil Database (HWSD), Aster GeDEM (METI and NASA, 2011), and studies conducted in other similar contexts (e.g. unit costs of activities adopted from an ongoing Water Fund in Kenya). Table 1 summarizes the main biophysical data, specifying resolution and sources, and provide hints on their pre-processing. 
Table 1: Biophysical data processing for modeling soil erosion control in the Toker watershed

\begin{tabular}{|c|c|c|c|c|}
\hline Data & Resolution & Source & Reference & Note \\
\hline LULC & $1: 100000$ & Africover & $\begin{array}{l}\text { FAO GEONETWORK. Spatially } \\
\text { Aggregated Multipurpose Landcover } \\
\text { Database for Eritrea - AFRICOVER } \\
\text { (GeoLayer). (Latest update: } 18 \text { Feb 2014) } \\
\text { Accessed (21 May 2015). } \\
\text { http://data.fao.org/ref/7d456921-5365-4958- } \\
\text { 8482-799de81dc8af.html?version=1.0 }\end{array}$ & $\begin{array}{l}\text { Africover land use and land cover } \\
\text { was reclassified using the General } \\
\text { LULC classification proposed in } \\
\text { RIOS Approach (see } \\
\text { Supplementary Material - Part I) }\end{array}$ \\
\hline DEM & $30 \mathrm{~m}$ & $\begin{array}{l}\text { Aster } \\
\text { Gedem }\end{array}$ & $\begin{array}{l}\text { METI and NASA (2011) ASTER GDEM } \\
\text { Version 2. Accessed (May 2014). } \\
\text { http://gdem.ersdac.jspacesystems.or.jp/ }\end{array}$ & \\
\hline $\begin{array}{l}\text { Rainfall } \\
\text { erosivity }\end{array}$ & $\begin{array}{l}900 \text { arc } \\
\text { sec }\end{array}$ & $\begin{array}{l}\text { Vrieling } \\
\text { et al. }\end{array}$ & $\begin{array}{l}\text { Satellite-based estimation (Vrieling et al., } \\
\text { 2010) }\end{array}$ & $\begin{array}{l}\text { Obtained from Vrieling et al., } \\
\text { (2010) based on 3-hourly TRMM } \\
\text { Multi-satellite Precipitation } \\
\text { Analysis (TMPA) precipitation } \\
\text { data. }\end{array}$ \\
\hline $\begin{array}{l}\text { Soil } \\
\text { erodibility } \\
\text { and depth }\end{array}$ & $30 \operatorname{arc~sec}$ & HWSD & $\begin{array}{l}\text { FAO, IIASA, ISRIC, ISSCAS, and JRC. } \\
\text { (2012). Harmonized World Soil Database } \\
\text { (version 1.2). FAO, Rome, Italy and } \\
\text { IIASA, Laxenburg, Austria. }\end{array}$ & $\begin{array}{l}\text { Obtained following the analysis } \\
\text { described in } \\
\text { http://forums.naturalcapitalproject.org } \\
\text { /index.php?p=/discussion/comment/1 } \\
\text { 384/\#Comment_1384; (last accessed } \\
\text { 21/05/2015) }\end{array}$ \\
\hline
\end{tabular}

\subsection{Applying ecosystem service models}

Watershed investments. Out of the 60 possible investment scenarios defined in Section 4.3, only 38 scenarios were actually investigated, and the remaining 22 were found to be unfeasible because of some circumstantial and/or biophysical factors. For instance, areal extension of native vegetation in the TW was so small that, a limited budget (\$10.000) suffices to cover the whole area. In other cases, increased budget level did not result in a change of the selected ecosystem service.

Figure 5 compares, by way of example, two investment portfolios related to urban water security (upper panel) and rural poverty alleviation (lower panel). Both investment portfolios refer to an annual budget of US $\$ 100.000$ and budget allocation based on cost-effectiveness. It is possible to compare the yearly progress of the investment portfolios, with colors representing different watershed activities. Both portfolios invest in only two types of activities (i.e. agricultural vegetation management and protection), which also are the least expensive ones (both US\$125 per ha against US\$310 per ha for terracing or US $\$ 1010$ per ha for restoration). Spatially, in both cases watershed activities tend to concentrate along the river networks, which is coherent with a generally higher cost-effectiveness of investments in riparian buffers (See model description in Vogl et. al., 2015). In the case of rural poverty alleviation, however, there is a marked preference of activities in the two priority sub-watersheds (i.e. AdiSheka and AdiNfas_D01), which are almost entirely covered, by the end of the ten-year planning period. 

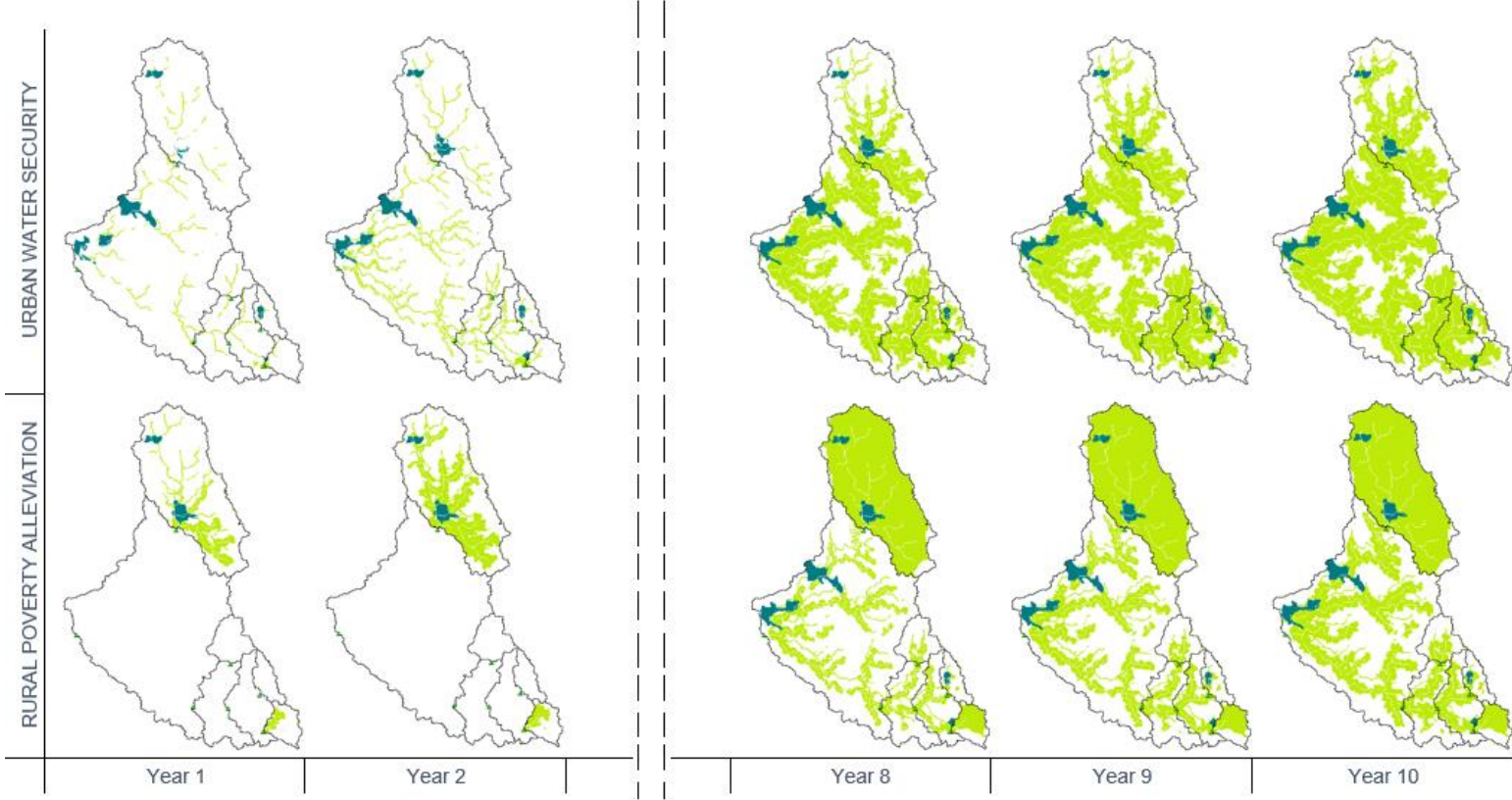

Figure 5: Comparing yearly progress of two investment portfolios, aiming at the two investment objectives, with a budget of $\$ 100.000$ that is allocated cost-effectively

Figure 6 shows another illustrative result, which allows to explore the role of the overall budget in shaping the investments portfolio. The example refers to scenarios in which the budget is entirely pre-allocated to assisted restoration. Here, worth noticing is the marked spatial mismatch between investment portfolios aiming at the two investment objectives.

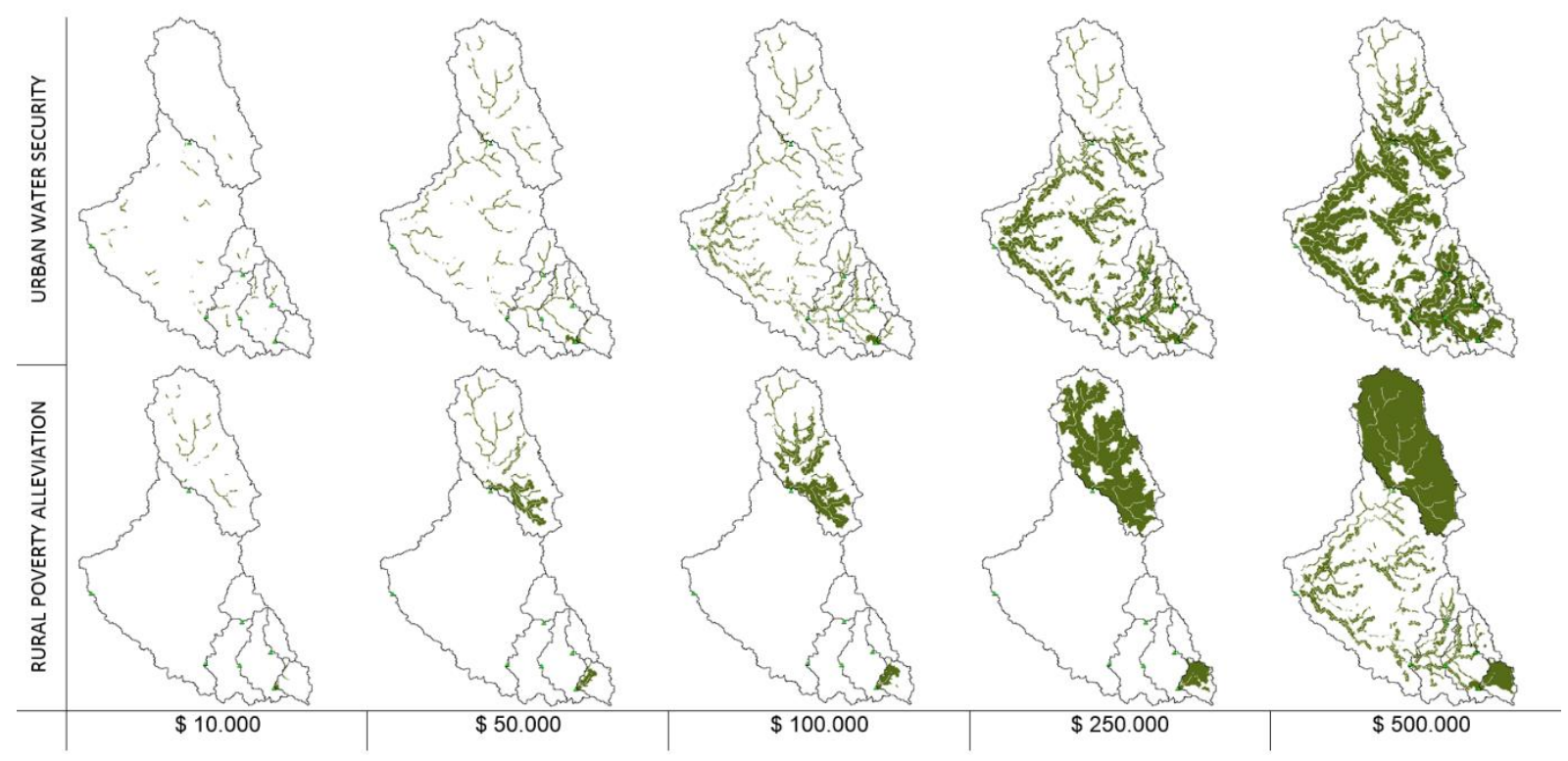

Figure 6: Comparing ten investment portfolios, aiming at the two investment objectives, with five different budget levels, each pre-allocated entirely to restoration 
In the Part III of the Supplementary Material, we provide two table that synthesize the 38 investment portfolios; for each scenario, they specify the amount of money actually spent in each activity and areal extension of the activity.

Impact on soil erosion control. Figure 7 shows soil erosion per unit area, at sub-watershed level, with darker colors meaning higher soil erosion. It compares eight investment portfolios (i.e. two WI objectives and four budgets levels, entirely pre-allocated to agricultural vegetation management), highlighting how the budget level affects the spatial configuration of the changes in ecosystem services. For instance, it shows the spatial mismatch between the two objectives is higher at lower budget levels. For rural poverty alleviation, the reduction of soil erosion in the priority sub-watershed AdiSheka is higher than for urban water security. At higher budgets, on the other hand, the mismatch between the two WI objectives tends to level off.

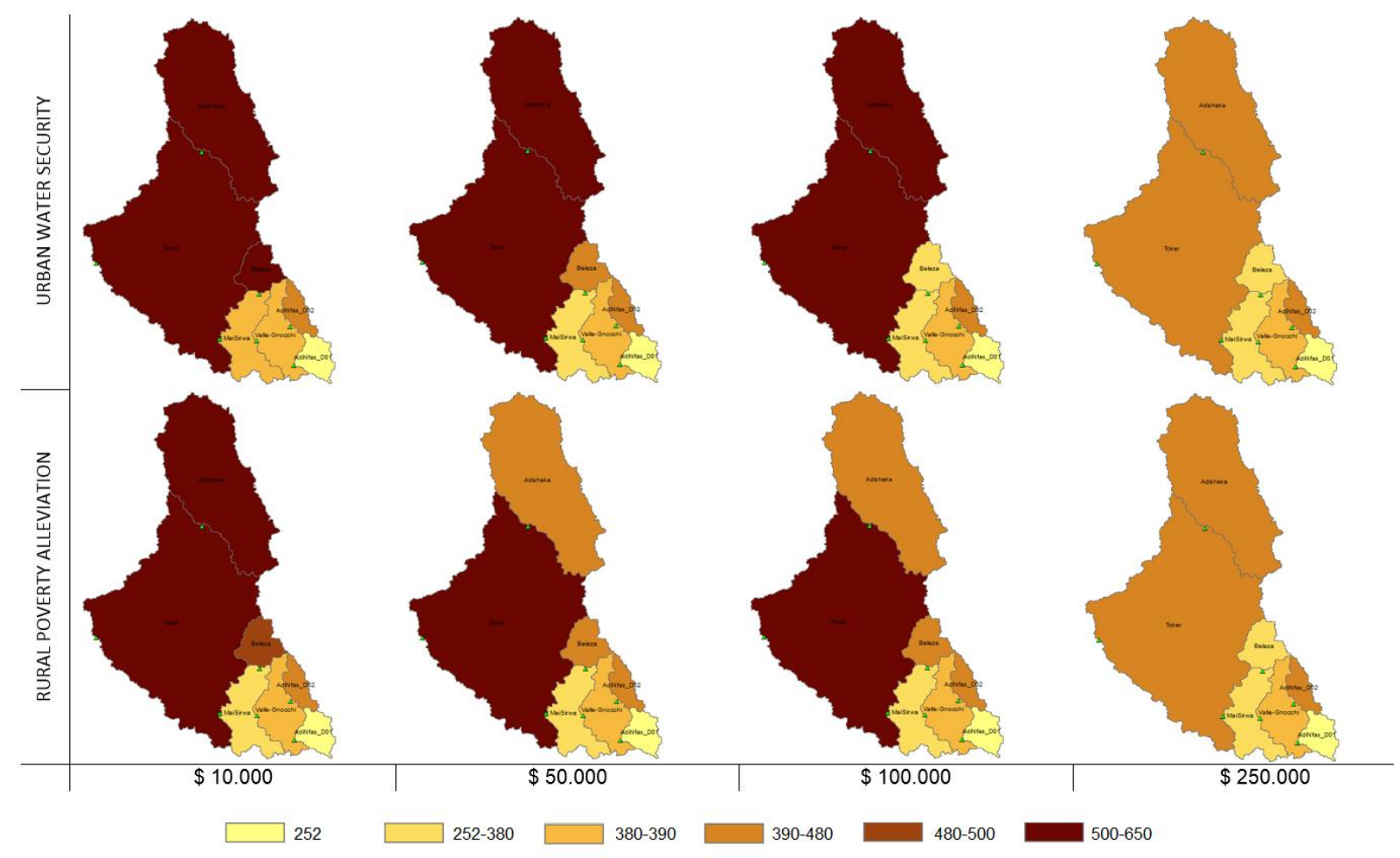

Figure 7: Comparing soil erosion per unit area, at sub-watershed level, for 8 investment portfolios aiming at the two WI objectives, with four different budgets levels, pre-allocated to agricultural vegetation management

\subsection{Assessing performance of investment scenarios and planning a follow-up}

Soil erosion reduction is a relevant ecosystem service, and thus was selected as an indicator of performance in this case study. The reduction corresponds to an enhancement of the ecosystem service, due to a combined effect of a decrease in sediment export and an increase of retention in the watershed (See model description in Vogl et al., 2015) Each investment scenario was characterized by the percentage reduction of soil erosion with respect to the baseline conditions, also at sub-watershed level. Table 2 summarizes the overall performance of the 38 investment portfolios, and, by way of example, the performance at sub-watershed level of the costeffectiveness scenarios, as well. It highlights the effects of the budget level and budget 
allocation modality on performance with respect to the two WI objectives. For example, in the case of investment for urban water security and an overall budget of $\$ 100.000$, the reduction of soil erosion, at watershed level, is of $15.3 \%$ (cost-effectiveness), 19.7\% (agricultural vegetation management), 6.6\% (assisted restoration), and 9\% (terracing). Such values reflect the combined role of the unit cost and of the effectiveness of the activities. This table also allows comparing investments aiming at the two WI objectives, for example, by calculating the difference in performance. A similar analysis has shown that, at watershed level, especially for higher budget levels, the difference tend to be null, and in any case less than four percent.

Table 2: Synthesis of the performance of the 38 investment portfolios in the case study, expressed in percentage reduction of soil erosion at watershed, and sub-watershed level (e.g. cost-effectiveness). See the Supplementary Material - Part III for expanded version.

\begin{tabular}{|c|c|c|c|c|c|c|c|c|c|c|c|c|}
\hline & \multicolumn{6}{|c|}{ URBAN WATER ECURITY } & \multicolumn{6}{|c|}{ RURAL POVERTY ALLEVIATION } \\
\hline & $\$ 10 K$ & $\$ 50 K$ & $\$ 100 K$ & $\$ 250 \mathrm{~K}$ & $\$ 500 K$ & $\$ 1000 K$ & $\$ 10 K$ & $\$ 50 K$ & $\$ 100 K$ & $\$ 250 K$ & $\$ 500 K$ & $\$ 1000 K$ \\
\hline Cost-effect. & $-2.2 \%$ & $-7.3 \%$ & $-15.3 \%$ & $-25.4 \%$ & & & $1.8 \%$ & $-5.0 \%$ & $-15.2 \%$ & $-25.4 \%$ & & \\
\hline Toker. & $-0.7 \%$ & $2.6 \%$ & $-10.1 \%$ & $-24.5 \%$ & & & $3.3 \%$ & $-6.1 \%$ & $-15.8 \%$ & $-24.5 \%$ & & \\
\hline AdiSheka & $-5.5 \%$ & $-29.0 \%$ & $-29.6 \%$ & $-32.2 \%$ & & & $-0.3 \%$ & $-4.0 \%$ & $-17.4 \%$ & $-32.2 \%$ & & \\
\hline Maisirwa & $-2.8 \%$ & $-8.7 \%$ & $-14.1 \%$ & $-28.6 \%$ & & & $-0.3 \%$ & $-5.3 \%$ & $-14.0 \%$ & $-28.6 \%$ & & \\
\hline Beleza & $-2.3 \%$ & $-7.6 \%$ & $-18.9 \%$ & $-33.8 \%$ & & & $0.4 \%$ & $1.6 \%$ & $1.6 \%$ & $0.9 \%$ & & \\
\hline Valle-Gnocchi & $0.0 \%$ & $-0.4 \%$ & $1.2 \%$ & $0.9 \%$ & & & $-1.6 \%$ & $-10 \%$ & $-24.3 \%$ & $-33.8 \%$ & & \\
\hline AdiNifas_Do1 & $0.4 \%$ & $0.4 \%$ & $0.4 \%$ & $0.4 \%$ & & & $0.4 \%$ & $0.4 \%$ & $0.4 \%$ & $0.4 \%$ & & \\
\hline AdiNifas_D02 & $0.0 \%$ & $4.9 \%$ & $5.0 \%$ & $5.0 \%$ & & & $5.0 \%$ & $5.0 \%$ & $5.0 \%$ & $5.0 \%$ & & \\
\hline Ag. Veg.* & $-3.0 \%$ & $-10.9 \%$ & $-19.7 \%$ & $-28.8 \%$ & & & $-1.7 \%$ & $-9.7 \%$ & $-19.7 \%$ & $-28.8 \%$ & & \\
\hline Protection & $3.4 \%$ & & & & & & $3.4 \%$ & & & & & \\
\hline Restoration & $-0.5 \%$ & $-2.9 \%$ & $-6.6 \%$ & $-13.6 \%$ & $-21.4 \%$ & $-39.1 \%$ & $-0.3 \%$ & $-1.8 \%$ & $-3.4 \%$ & $-9.2 \%$ & $-20.3 \%$ & $-40.0 \%$ \\
\hline Terracing & $-1.3 \%$ & $-5.4 \%$ & $-9.0 \%$ & $-15.5 \%$ & & & $-0.8 \%$ & $-4.2 \%$ & $-8.7 \%$ & $-15.5 \%$ & & \\
\hline
\end{tabular}

The aggregated performance values in Table 2 combined with the feasibility and/or desirability considerations of stakeholders seen in Section 4.3 are essential in order to reach the necessary consensus over the actual WI scenario to be implemented. We here recall that the comparison between different WI scenarios is also supported by spatially, and temporally explicit data, such as maps of activities, future land use scenarios, and impact on selected ecosystem services (Section 4.5). Such data provide detailed guidance for the actual implementation of the WIs and at the same time form a strong basis for planning a follow-up. According to Morrison-Saunders et al. (2007), the later comprises four elements: monitoring (i.e. collection of pre and postimplementation activity and environmental data); evaluation (i.e. appraisal of the conformance with standards, predictions or expectations); management (i.e. making decisions and taking appropriate action in response to issues arising from monitoring and evaluation); and communication (i.e. updating the stakeholders to provide feedback on project and process). Indeed, the outputs of the technical component can easily feed the follow-up planning process. 


\section{Discussion}

The research presented in this paper partly addressed the main hindrances to the operationalization of the concept of ecosystem services. According to Turner and Daily (2008), the hindrances include "information failure", i.e. lack of detailed information at scales relevant to decision-making; "market failure", i.e. lack of compelling models of success, aligning economic incentives with conservation; and "institutional failure", lack of practical know-how in the process of institutional design and implementation. The case study application directly addressed the "information failure", providing detailed answers to some key management and planning questions; at the same time, it contributed to tackling the other two failures, as well. The simple approach for budgeting WIs that accounts for the loss aversion bias of stakeholders, recalling the New York City case study where budgeting was favorably influenced by an ecosystem service approach, is a good example.

At the same time, this study also built on the framework of boundary work by Clark et al. (2016), which provides guidance on collaborative knowledge generation for an adaptive ecosystem management, and establishment of good working relations among diverse stakeholders to promote cooperative implementation. Here mentioned is the distinction between two components (strategic and technical) and three stages, which reflect the different needs of boundary work, in order to effectively and timely facilitate negotiation among stakeholders engaged in knowledge use and production. The strategic component mainly ensures saliency and legitimacy, while the technical component ensures credibility. Yet, the two components are tightly interlinked. In fact, only jointly do they actually contribute to a successful implementation of WIs, by linking diverse sets of stakeholders and knowledge systems, across different management levels and institutional boundaries (Kowalki and Jenkins, 2015). Moreover, as Parker and Corona (2012) put it, boundary work is part of a dynamic process that takes place in a "landscape of tensions", rather than a single-time achievement. Thus, the importance of gaining a good understanding of the contextual and contingent factors of the specific socio-ecological system, as well as the relative influence of the involved social actors, to determine the different boundary work needs.

Our empirical test of the technical component illustrated the applicability of the proposed approach to medium-sized cities in a data poor context in Sub-Saharan Africa. These are the cities that are expected to host the majority of urban population growth in the next decade (UN, 2014). We consciously selected the case study knowing that data paucity, and resource scarcity are two challenging factors. Similarly, soil erosion- and water scarcity-related issues are among the most common issues affecting many medium-sized cities in Africa. The case study application highlighted the main challenges in terms of data paucity and boundary work that should be put in place to facilitate the negotiation among stakeholders. In particular, data paucity affected the results of the analysis, for example, some data used in this paper had low resolution such as in the case of the rainfall erosivity provided by Vrieling et al. (2010). Boundary work wise, local knowledge and experience should be preferred to better characterize watersheds and watershed activities. This is particularly valuable for ensuring saliency and legitimacy during the process of WIs design and assessment, and beyond. In addition, our analysis did not include calibration of the models and relied on some assumptions regarding for instance the unit costs of activities. Indeed, another area for further stakeholder input could 
involve obtaining observed data for calibration and validation of results, as well as data on cost of activities and their effectiveness.

Despite these limitations, the case study application highlighted the potential of the proposed approach to support implementation of WI, and ultimately promote adaptive watershed management. To this end, two illustrative watershed initiatives that could represent "windows of opportunity" for applying the proposed approach in the TW were identified. These two watershed initiatives are representative of the contextual and contingent factors as well as the relative influence of stakeholders in the case study. A first initiative consists of existing partnerships between the Asmara water utility and farmers in the Central Region, in which the TW is located. Currently, the utility provides agricultural extension service to farmers, organized in five associations, each having a management committee, consisting of a chairperson, secretary and treasurer (Abraham et al., 2009). The associations include 1.126 farmer members, which receive technical and financial support from the utility (Abraham et al., 2009). A second initiative is a so-called Summer Student Work Program (SSWP). Launched by the Ministry of Education in 1994, it engages secondary school students in a wide range of activities, including forestation, soil and water conservation, and assisting poor farmers. The SSWP is a valuable socio-ecological "experiment", allowing students with urban background to reconnect to nature and interact with farmers of different social-ethnic-economic extraction. At the same time, it contributes to the restoration of ecosystems and their services, often directly benefiting the rural communities, as well as assists poor farmers. Quite interesting is an assessment of the first 15 years of the SSWP, carried out in 2009. Among others, the assessment highlighted how currently the identification of the areas of intervention heavily relies on expertbased approaches, which lack the needed flexibility to form the basis of an iterative scienceinformed decision support system. Moreover, the assessment registered a high willingness of the farmers to get involved in the various soil and water conservation initiatives.

From an adaptive watershed management perspective, these two initiatives provide an interesting point of departure. Singularly, each could benefit from the application of the here proposed approach. For the first initiative, by introducing an ecosystem services perspective, the approach has the potential to boost the existing cooperation by shifting it to a higher level (e.g. PES schemes). While for the SSWP, it could ensure that its activities are designed based on sound scientific information, by coherently combining experts', and farmers' knowledge. Perhaps, this ecosystem services-, and boundary work-based approach, could trigger a process of social learning, involving the stakeholders in these two initiatives, within a framework of adaptive watershed management, eventually, with the Asmara water utility as a central actor. In general, we hope that this study will inspire other medium-sized cities in Sub-Sharan Africa to experiment innovative and creative ways of facing their challenges, based on the concepts of ecosystem services and boundary work.

\section{Conclusions}

This paper proposed an operative approach for designing and assessing the impact of WIs, and tested its technical component in a data scarce case study. The approach utilized ecosystem services modeling, and boundary work. Pragmatically, it can effectively support the design and 
assessment of the impact of WIs that aim at urban water security along with other social or environmental objectives. By addressing stakeholders' concerns of credibility, saliency, and legitimacy, the methodology can facilitate negotiation of objectives, definition of scenarios, assessment of alternative watershed investments, and planning a follow-up, to tackle local challenges, ultimately, to help achieve resilient socio-ecological system. By considering WIs as strong implementation tools, we believe the approach has good potential to trigger and support the implementation of an adaptive watershed management (Pahl-Wostl et al., 2007, 2011).

In addition, this research contributes to embedding resilience thinking into impact assessment, by incorporating at least three of the five changes to "business as usual impact assessment", as suggested by Bond et al. (2015). More specifically, the strategic component clearly identifies as key inputs of the process of WI design and assessment, the definition of objectives and visioning of feasible and desirable scenarios by stakeholders. The technical component applies spatially explicit modelling to first design WI, hence to model the impacts on selected ecosystem services. Last, the here proposed approach was conceived within a framework of adaptive watershed management, in order to address its key challenge: linking diverse stakeholders and knowledge system across management levels and institutional boundaries.

\section{Acknowledgement}

We are indebted to many individuals and organizations, including the Natural Capital Project (NatCap) (http://www.naturalcapitalproject.org/) for its open source software tools. In particular, we are grateful to Stacie Wolny, Yonas Ghile, and Adrian Vogl (NatCap) for their technical support, supply of data, and comments on a first draft on this paper. We are thankful to Eng. Kidane Kiflemariam (Asmara Department of Water Supply) for sharing his extensive industry experience, knowledge, and points of view about the case study. Thanks to Vrieling Anton (ITC) for providing us with data of rainfall erosivity and thanks to Mr. Petros Hailemariam (Eritrean Ministry of Education) for sharing the report on the evaluation of the "Summer Student Work Program". We are grateful to Parveen Kumar and Umesh Sigh for their help with GIS, to Karina Cano Paoli and Luigi Calabrese for reviewing a draft, and to Elena Ianni, Chiara Cortinovis, and Mohamed Abdu Ahmed for proofreading this article several times. Last, we are grateful to the two reviews and the editors for their supportive comments. 


\section{Vitae}

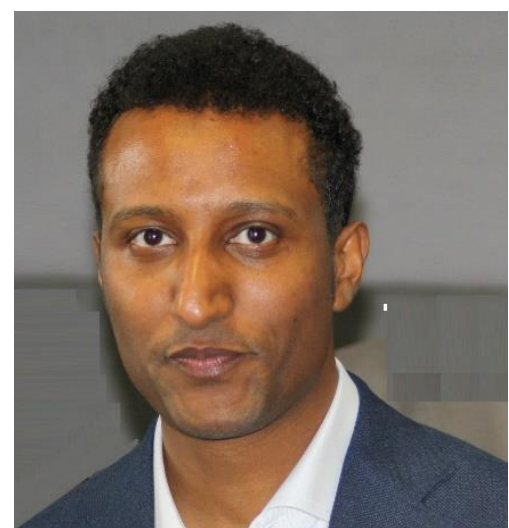

Blal Adem Esmail, a postdoctoral research fellow at the University of Trento and member of the Planning for Ecosystem Services (PLANES) research group http://www.planningfores.com/, is interested in applying ecosystem services to improve real-life decisions, including project design, planning and policy-making. He works on operationalizing an ecosystem service approach for watershed management and planning, focusing on urban water infrastructures and institutions. He is currently involved in the EU Horizon 2020 Project ESMERALDA http://www.esmeralda-project.eu/, developing case studies on the use of ecosystem services for policymaking. Formerly, he worked as technical manager and consultant in the fields of oil research and building construction.

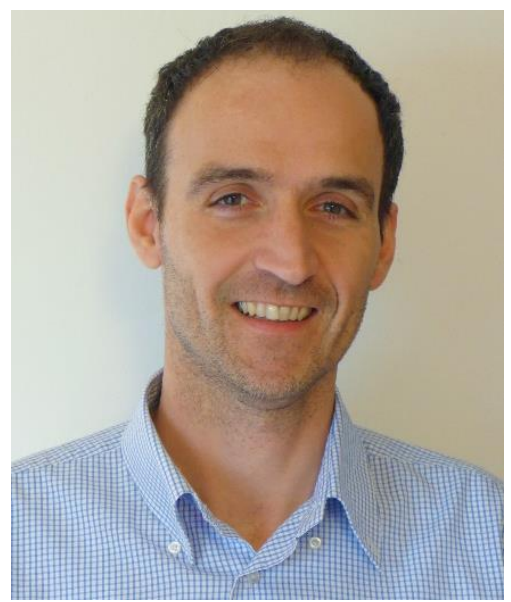

Davide Geneletti Associate Professor of Spatial Planning at the University of Trento. Specialised in impact assessment of projects, plans and policies; ecosystem services; multicriteria analysis. Formerly Research Fellow at Harvard University's Sustainability Science Program (2010-11), and Visiting Scholar at Stanford University's Woods Institute for the Environment (2014). He has consulted for private and public bodies internationally, including the United Nations Environment Programme (UNEP), UN-HABITAT, and the European Commission. Editor of the Journal of Environmental Assessment Policy and Management and Deputy Editor and cofounder of the journal One Ecosystem. Founding member of the start-up company Skopia, specialized in anticipation services for environmental, social and economic planning. 


\section{$9 \quad$ Reference}

Abraham, D., Tesfaslasie, F., Tesfay, S., 2009. An Appraisal of the Current Status and Potential of Surface Water in the Upper Anseba Catchment Potential of Surface Water in the Upper Anseba Catchment. doi:10.7892/boris.69703

Abson, D.J., von Wehrden, H., Baumgärtner, S., Fischer, J., Hanspach, J., Härdtle, W., Heinrichs, H., Klein, a. M., Lang, D.J., Martens, P., Walmsley, D., 2014. Ecosystem services as a boundary object for sustainability. Ecol. Econ. 103, 29-37. doi:10.1016/j.ecolecon.2014.04.012

Berkes, F., 2009. Evolution of co-management: Role of knowledge generation, bridging organizations and social learning. J. Environ. Manage. 90, 1692-1702. doi:10.1016/j.jenvman.2008.12.001

Bond, A., Morrison-Saunders, A., Gunn, J.A.E., Pope, J., Retief, F., 2015. Managing uncertainty, ambiguity and ignorance in impact assessment by embedding evolutionary resilience, participatory modelling and adaptive management. J. Environ. Manage. 151, 97-104. doi:10.1016/j.jenvman.2014.12.030

Bond, A., Morrison-Saunders, A., Pope, J., 2012. Sustainability assessment: the state of the art. Impact Assess. Proj. Apprais. 30, 53-62. doi:10.1080/14615517.2012.661974

Cash, D.W., Clark, W.C., Alcock, F., Dickson, N.M., Eckley, N., Guston, D.H., Jager, J., Mitchell, R.B., 2003. Knowledge systems for sustainable development. Proc. Natl. Acad. Sci. 100, 80868091. doi:10.1073/pnas.1231332100

Clark, W.C., Tomich, T.P., van Noordwijk, M., Guston, D., Catacutan, D., Dickson, N.M., McNie, E., 2016. Boundary work for sustainable development: Natural resource management at the Consultative Group on International Agricultural Research (CGIAR). Proc. Natl. Acad. Sci. 113, 4615-4622. doi:10.1073/pnas.0900231108

Cortner, H.J., Moote, M.A., 1994. Trends and issues in land and water resources management: Setting the agenda for change. Environ. Manage. 18, 167-173. doi:10.1007/BF02393759

Daw, T., Brown, K., Rosendo, S., Pomeroy, R., 2011. Applying the ecosystem services concept to poverty alleviation: the need to disaggregate human well-being. Environ. Conserv. 38, 370-379. doi:10.1017/S0376892911000506

de Groot, R.S., Alkemade, R., Braat, L., Hein, L., Willemen, L., 2010. Challenges in integrating the concept of ecosystem services and values in landscape planning, management and decision making. Ecol. Complex. 7, 260-272. doi:10.1016/j.ecocom.2009.10.006

Geneletti, D., 2015. A Conceptual Approach to Promote the Integration of Ecosystem Services in Strategic Environmental Assessment. J. Environ. Assess. Policy Manag. 17, 1550035. doi:10.1142/S1464333215500350

Geneletti, D., 2013. Assessing the impact of alternative land-use zoning policies on future ecosystem services. Environ. Impact Assess. Rev. 40, 25-35. doi:10.1016/j.eiar.2012.12.003

Geneletti, D., Zardo, L., Cortonovis, C., 2016. Nature-based solutions for climate adaptation: Case studies in impact assessment for urban planning, in: Geneletti, D. (Ed.), Handbook on Biodiversity and Ecosystem Services in Impact Assessment. Edward Elgar.

Gleick, P.H., 2000. A Look at Twenty-first Century Water Resources Development. Water Int. 25, 127-138. doi:10.1080/02508060008686804

Guerry, A.D., Polasky, S., Lubchenco, J., Chaplin-Kramer, R., Daily, G.C., Griffin, R., Ruckelshaus, M., Bateman, I.J., Duraiappah, A., Elmqvist, T., Feldman, M.W., Folke, C., Hoekstra, J., Kareiva, P.M., Keeler, B.L., Li, S., McKenzie, E., Ouyang, Z., Reyers, B., Ricketts, T.H., 
Rockström, J., Tallis, H., Vira, B., 2015. Natural capital and ecosystem services informing decisions: From promise to practice. Proc. Natl. Acad. Sci. 112, 201503751. doi:10.1073/pnas.1503751112

Haase, D., Frantzeskaki, N., Elmqvist, T., 2014. Ecosystem services in urban landscapes: Practical applications and governance implications. Ambio 43, 407-412. doi:10.1007/s13280-014-0503-1

Habtetsion, S., Tsighe, Z., 2007. Energy sector reform in Eritrea: initiatives and implications. J. Clean. Prod. 15, 178-189. doi:10.1016/j.jclepro.2005.09.003

Hacking, T. and Guthrie, P., 2006. Sustainable development objectives in impact assessment: why are they needed and where do they come from? Journal of Environmental Assessment Policy and Management, 341-371. doi:10.1142/S1464333206002554

Higgins, J.V., Zimmerling, A. (Eds.), 2013. A Primer for Monitoring Water Funds. Global Freshwater Program. The Nature Conservancy, Arlington, VA.

Howe, C., Suich, H., Vira, B., Mace, G.M., 2014. Creating win-wins from trade-offs? Ecosystem services for human well-being: A meta-analysis of ecosystem service trade-offs and synergies in the real world. Glob. Environ. Chang. 28, 263-275. doi:10.1016/j.gloenvcha.2014.07.005

IPCC, 2014. Summary for Policy Makers, in: Field, C.B., Barros, V.R., Dokken, D.J., K.J., M., Mastrandrea, M.D., Bilir, T.E., Chatterjee, M., Ebi, K.L., Estrada, Y.O., Genova, R.C., Girma, B., Kissel, E.S., Levy, A.N., MacCracken, S., Mastrandrea, P.R., White, L.L. (Eds.), Climate Change 2014: Impacts, Adaptation and Vulnerability - Contributions of the Working Group II to the Fifth Assessment Report Report of the Intergovernmental Panel on Climate Change. Cambridge University Press, Cambridge, UK \& New York, NY, USA, pp. 1-32 pp.

Kahneman, D., Tversky, A., 1984. Choices, values, and frames. Am. Psychol. 39, 341-350. doi:10.1037/0003-066X.39.4.341

Kowalski, A.A., Jenkins, L.D., 2015. The role of bridging organizations in environmental management : examining social networks in working groups. Ecol. Soc. 20, 16. doi:10.5751/ES07541-200216

Lamorgese, L., D. Geneletti. 2015. Equity in sustainability assessment: A conceptual framework. In: A. Morrison-Saunders, J. Pope and A. Bond (Eds.), Handbook of Sustainability Assessment. Edgar Elgar Publishing Ltd.

Landsberg, F., Treweek, J., Stickler, M.M., Henninger, N., Venn, O., 2013. Weaving ecosystem services into impact assessment. A step-By-Step Method (Version 1.0), 1.0 ed. World Resources Institute, Washington, DC.

Lawler, J.J., Lewis, D.J., Nelson, E., Plantinga, a. J., Polasky, S., Withey, J.C., Helmers, D.P., Martinuzzi, S., Pennington, D., Radeloff, V.C., 2014. Projected land-use change impacts on ecosystem services in the United States. Proc. Natl. Acad. Sci. 111, 7492-7497. doi:10.1073/pnas.1405557111

Maes, J., Egoh, B., Willemen, L., Liquete, C., Vihervaara, P., Schägner, J.P., Grizzetti, B., Drakou, E.G., Notte, A. La, Zulian, G., Bouraoui, F., Luisa Paracchini, M., Braat, L., Bidoglio, G., 2012. Mapping ecosystem services for policy support and decision making in the European Union. Ecosyst. Serv. 1, 31-39. doi:10.1016/j.ecoser.2012.06.004

Mandle, L., Bryant, B.P., Ruckelshaus, M., Geneletti, D., Kiesecker, J.M., Pfaff, A., 2015. Entry Points for Considering Ecosystem Services within Infrastructure Planning: How to Integrate Conservation with Development in Order to Aid Them Both. Conserv. Lett. 0, n/a-n/a. doi:10.1111/conl.12201 
METI and NASA, 2011. ASTER GDEM Version 2. Accessed (May 2014).

URL:http://gdem.ersdac.jspacesystems.or.jp/

McDonald, R.I., Shemie, D., 2014. Urban Water Blueprint: Mapping conservation solutions to the global water challenge. The Nature Conservancy, Washington, DC.

Mitchell, R.B., Clark, W.C., Cash, D.W., Dickson, N.M., 2006. Global Environmental Assessments: Information And Influence. MIT Press, Cambridge, MA.

MoLWE, 2012. Eritrea's Second National Communication Under the United Nations Framework Convention on Climate Change (UNFCCC). Asmara, Eritrea.

Morrison-Saunders, A., Marshall, R., Arts, J., 2007. EIA Follow-Up International Best Practice Principles. Special Publication Series No. 6. Int. Assoc. Impact Assess.

Niaz Murtaza, 1998. The Pillage of Sustainability in Eritrea, 1600s-1990s: Rural Communities and the Creeping Shadows of Hegemony. Westport, CT, Greenwood Press.

Pagella, T.F., Sinclair, F.L., 2014. Development and use of a typology of mapping tools to assess their fitness for supporting management of ecosystem service provision. Landsc. Ecol. 29, 383-399. doi:10.1007/s10980-013-9983-9

Pahl-Wostl, C., 2002. Towards sustainability in the water sector - The importance of human actors and processes of social learning. Aquat. Sci. 64, 394-411. doi:10.1007/PL00012594

Pahl-Wostl, C., Jeffrey, P., Isendahl, N., Brugnach, M., 2011. Maturing the New Water Management Paradigm: Progressing from Aspiration to Practice. Water Resour. Manag. 25, 837-856. doi:10.1007/s11269-010-9729-2

Polasky, S., Nelson, E., Camm, J., Csuti, B., Fackler, P., Lonsdorf, E., Montgomery, C., White, D., Arthur, J., Garber-Yonts, B., Haight, R., Kagan, J., Starfield, A., Tobalske, C., 2008. Where to put things? Spatial land management to sustain biodiversity and economic returns. Biol. Conserv. 141, 1505-1524. doi:10.1016/j.biocon.2008.03.022

Pope, J., Annandale, D., Morrison-Saunders, A., 2004. Conceptualising sustainability assessment. Environ. Impact Assess. Rev. 24, 595-616. doi:10.1016/j.eiar.2004.03.001Ruckelshaus, M., McKenzie, E., Tallis, H., Guerry, A., Daily, G., Kareiva, P., Polasky, S., Ricketts, T., Bhagabati, N., Wood, S. a., Bernhardt, J., 2015. Notes from the field: Lessons learned from using ecosystem service approaches to inform real-world decisions. Ecol. Econ. 115, 11-21. doi:10.1016/j.ecolecon.2013.07.009

Sharp, R., Tallis, H.T., Ricketts, T., Guerry, A.D., Wood, S.A., Chaplin-Kramer, R., Nelson, E., Ennaanay, D., Wolny, S., Olwero, N., Vigerstol, K., Pennington, D., Mendoza, G., Aukema, J., Foster, J., Forrest, J., Cameron, D., Arkema, K., Lonsdorf, E., Kennedy, C., Verutes, G., Kim, C.K., Guannel, G., Papenfus, M., Toft, J., Marsik, M., Bernhardt, J., Griffin, R., Glowinski, K., Chaumont, N., Perelman, A., Lacayo, M. Mandle, L., Hamel, P., Vogl, A.L., Rogers, L., and Bierbower, W. 2015. InVEST 3.2.0 User's Guide. The Natural Capital Project, Stanford University, University of Minnesota, The Nature Conservancy, and World Wildlife Fund.

Star, S.L., Griesemer, J.R., 1989. Institutional Ecology, 'Translations' and Boundary Objects: Amateurs and Professionals in Berkeley's Museum of Vertebrate Zoology, 1907-39. Soc. Stud. Sci. 19, 387-420. doi:10.1177/030631289019003001

Tallis, H., Kennedy, C.M., Ruckelshaus, M., Goldstein, J., Kiesecker, J.M., 2015. Mitigation for one $\&$ all: An integrated framework for mitigation of development impacts on biodiversity and ecosystem services. Environ. Impact Assess. Rev. 55, 21-34. doi:10.1016/j.eiar.2015.06.005

TEEB, 2010. The Economics of Ecosystems and Biodiversity: Ecological and Economic Foundations. 
In: Pushpam Kumar (Ed.), Earthscan, London and Washington.

Tewolde, M.G., Cabral, P., 2011. Urban Sprawl Analysis and Modeling in Asmara, Eritrea. Remote Sens. 3, 2148-2165. doi:10.3390/rs3102148

Turner, R.K., Daily, G.C., 2008. The Ecosystem Services Framework and Natural Capital Conservation. Environ. Resour. Econ. 39, 25-35. doi:10.1007/s10640-007-9176-6

UN, D., 2014. World Urbanization Prospects The 2014 Revision, Highlights.

Vogl, A., Tallis, H., Douglass, J., Sharp, R., Wolny, S., Veiga, F., Benitez, S., León, J., Game, E., Petry, P., Guimerães, J., Lozano, J.S., 2015. Resource Investment Optimization System (RIOS). v1.1.0. Introduction and Theoretical Documentation. Stanford (CA).

Vrieling, A., Sterk, G., de Jong, S.M., 2010. Satellite-based estimation of rainfall erosivity for Africa. J. Hydrol. 395, 235-241. doi:10.1016/j.jhydrol.2010.10.035

Abraham, D., Tesfaslasie, F., Tesfay, S., 2009. An Appraisal of the Current Status and Potential of Surface Water in the Upper Anseba Catchment Potential of Surface Water in the Upper Anseba Catchment. doi:10.7892/boris.69703

Abson, D.J., von Wehrden, H., Baumgärtner, S., Fischer, J., Hanspach, J., Härdtle, W., Heinrichs, H., Klein, a. M., Lang, D.J., Martens, P., Walmsley, D., 2014. Ecosystem services as a boundary object for sustainability. Ecol. Econ. 103, 29-37. doi:10.1016/j.ecolecon.2014.04.012

Berkes, F., 2009. Evolution of co-management: Role of knowledge generation, bridging organizations and social learning. J. Environ. Manage. 90, 1692-1702. doi:10.1016/j.jenvman.2008.12.001

Bond, A., Morrison-Saunders, A., Pope, J., 2012. Sustainability assessment: the state of the art. Impact Assess. Proj. Apprais. 30, 53-62. doi:10.1080/14615517.2012.661974

Cash, D.W., Clark, W.C., Alcock, F., Dickson, N.M., Eckley, N., Guston, D.H., Jager, J., Mitchell, R.B., 2003. Knowledge systems for sustainable development. Proc. Natl. Acad. Sci. 100, 80868091. doi:10.1073/pnas.1231332100

Cortner, H.J., Moote, M.A., 1994. Trends and issues in land and water resources management: Setting the agenda for change. Environ. Manage. 18, 167-173. doi:10.1007/BF02393759

Daw, T., Brown, K., Rosendo, S., Pomeroy, R., 2011. Applying the ecosystem services concept to poverty alleviation: the need to disaggregate human well-being. Environ. Conserv. 38, 370-379. doi:10.1017/S0376892911000506

de Groot, R.S., Alkemade, R., Braat, L., Hein, L., Willemen, L., 2010. Challenges in integrating the concept of ecosystem services and values in landscape planning, management and decision making. Ecol. Complex. 7, 260-272. doi:10.1016/j.ecocom.2009.10.006

Geneletti, D., 2015. A Conceptual Approach to Promote the Integration of Ecosystem Services in Strategic Environmental Assessment. J. Environ. Assess. Policy Manag. 17, 1550035. doi:10.1142/S1464333215500350

Geneletti, D., 2013. Assessing the impact of alternative land-use zoning policies on future ecosystem services. Environ. Impact Assess. Rev. 40, 25-35. doi:10.1016/j.eiar.2012.12.003

Geneletti, D., Zardo, L., Cortonovis, C., 2016. Nature-based solutions for climate adaptation: Case studies in impact assessment for urban planning, in: Geneletti, D. (Ed.), Handbook on Biodiversity and Ecosystem Services in Impact Assessment. Edward Elgar.

Gleick, P.H., 2000. A Look at Twenty-first Century Water Resources Development. Water Int. 25, 127-138. doi:10.1080/02508060008686804 
Guerry, A.D., Polasky, S., Lubchenco, J., Chaplin-Kramer, R., Daily, G.C., Griffin, R., Ruckelshaus, M., Bateman, I.J., Duraiappah, A., Elmqvist, T., Feldman, M.W., Folke, C., Hoekstra, J., Kareiva, P.M., Keeler, B.L., Li, S., McKenzie, E., Ouyang, Z., Reyers, B., Ricketts, T.H., Rockström, J., Tallis, H., Vira, B., 2015. Natural capital and ecosystem services informing decisions: From promise to practice. Proc. Natl. Acad. Sci. 112, 201503751. doi:10.1073/pnas.1503751112

Haase, D., Frantzeskaki, N., Elmqvist, T., 2014. Ecosystem services in urban landscapes: Practical applications and governance implications. Ambio 43, 407-412. doi:10.1007/s13280-014-0503-1

Habtetsion, S., Tsighe, Z., 2007. Energy sector reform in Eritrea: initiatives and implications. J. Clean. Prod. 15, 178-189. doi:10.1016/j.jclepro.2005.09.003

Higgins, J.V., Zimmerling, A. (Eds.), 2013. A Primer for Monitoring Water Funds. Global Freshwater Program. The Nature Conservancy, Arlington, VA.

Howe, C., Suich, H., Vira, B., Mace, G.M., 2014. Creating win-wins from trade-offs? Ecosystem services for human well-being: A meta-analysis of ecosystem service trade-offs and synergies in the real world. Glob. Environ. Chang. 28, 263-275. doi:10.1016/j.gloenvcha.2014.07.005

IPCC, 2014. Summary for Policy Makers, in: Field, C.B., Barros, V.R., Dokken, D.J., K.J., M., Mastrandrea, M.D., Bilir, T.E., Chatterjee, M., Ebi, K.L., Estrada, Y.O., Genova, R.C., Girma, B., Kissel, E.S., Levy, A.N., MacCracken, S., Mastrandrea, P.R., White, L.L. (Eds.), Climate Change 2014: Impacts, Adaptation and Vulnerability - Contributions of the Working Group II to the Fifth Assessment Report Report of the Intergovernmental Panel on Climate Change. Cambridge University Press, Cambridge, UK \& New York, NY, USA, pp. 1-32 pp.

Kahneman, D., Tversky, A., 1984. Choices, values, and frames. Am. Psychol. 39, 341-350. doi:10.1037/0003-066X.39.4.341

Kowalski, A.A., Jenkins, L.D., 2015. The role of bridging organizations in environmental management : examining social networks in working groups. Ecol. Soc. 20, 16. doi:10.5751/ES07541-200216

Landsberg, F., Treweek, J., Stickler, M.M., Henninger, N., Venn, O., 2013. Weaving ecosystem services into impact assessment. A step-By-Step Method (Version 1.0), 1.0 ed. World Resources Institute, Washington, DC.

Lawler, J.J., Lewis, D.J., Nelson, E., Plantinga, a. J., Polasky, S., Withey, J.C., Helmers, D.P., Martinuzzi, S., Pennington, D., Radeloff, V.C., 2014. Projected land-use change impacts on ecosystem services in the United States. Proc. Natl. Acad. Sci. 111, 7492-7497. doi:10.1073/pnas.1405557111

Maes, J., Egoh, B., Willemen, L., Liquete, C., Vihervaara, P., Schägner, J.P., Grizzetti, B., Drakou, E.G., Notte, A. La, Zulian, G., Bouraoui, F., Luisa Paracchini, M., Braat, L., Bidoglio, G., 2012. Mapping ecosystem services for policy support and decision making in the European Union. Ecosyst. Serv. 1, 31-39. doi:10.1016/j.ecoser.2012.06.004

Mandle, L., Bryant, B.P., Ruckelshaus, M., Geneletti, D., Kiesecker, J.M., Pfaff, A., 2015. Entry Points for Considering Ecosystem Services within Infrastructure Planning: How to Integrate Conservation with Development in Order to Aid Them Both. Conserv. Lett. 0, n/a-n/a. doi:10.1111/conl.12201

McDonald, R.I., Shemie, D., 2014. Urban Water Blueprint: Mapping conservation solutions to the global water challenge. The Nature Conservancy, Washington, DC.

Mitchell, R.B., Clark, W.C., Cash, D.W., Dickson, N.M., 2006. Global Environmental Assessments: Information And Influence. MIT Press, Cambridge, MA. 
MoLWE, 2012. Eritrea's Second National Communication Under the United Nations Framework Convention on Climate Change (UNFCCC). Asmara, Eritrea.

Morrison-Saunders, A., Marshall, R., Arts, J., 2007. EIA Follow-Up International Best Practice Principles. Special Publication Series No. 6. Int. Assoc. Impact Assess.

Pagella, T.F., Sinclair, F.L., 2014. Development and use of a typology of mapping tools to assess their fitness for supporting management of ecosystem service provision. Landsc. Ecol. 29, 383-399. doi:10.1007/s10980-013-9983-9

Pahl-Wostl, C., 2002. Towards sustainability in the water sector - The importance of human actors and processes of social learning. Aquat. Sci. 64, 394-411. doi:10.1007/PL00012594

Pahl-Wostl, C., Jeffrey, P., Isendahl, N., Brugnach, M., 2011. Maturing the New Water Management Paradigm: Progressing from Aspiration to Practice. Water Resour. Manag. 25, 837-856. doi:10.1007/s11269-010-9729-2

Parker, J., Crona, B., 2012. On being all things to all people: Boundary organizations and the contemporary research university. Soc. Stud. Sci. 42, 262-289. doi:10.1177/0306312711435833

Polasky, S., Nelson, E., Camm, J., Csuti, B., Fackler, P., Lonsdorf, E., Montgomery, C., White, D., Arthur, J., Garber-Yonts, B., Haight, R., Kagan, J., Starfield, A., Tobalske, C., 2008. Where to put things? Spatial land management to sustain biodiversity and economic returns. Biol. Conserv. 141, 1505-1524. doi:10.1016/j.biocon.2008.03.022

Pope, J., Annandale, D., Morrison-Saunders, A., 2004. Conceptualising sustainability assessment. Environ. Impact Assess. Rev. 24, 595-616. doi:10.1016/j.eiar.2004.03.001

Ruckelshaus, M., McKenzie, E., Tallis, H., Guerry, A., Daily, G., Kareiva, P., Polasky, S., Ricketts, T., Bhagabati, N., Wood, S. a., Bernhardt, J., 2015. Notes from the field: Lessons learned from using ecosystem service approaches to inform real-world decisions. Ecol. Econ. 115, 11-21. doi:10.1016/j.ecolecon.2013.07.009

Tallis, H., Kennedy, C.M., Ruckelshaus, M., Goldstein, J., Kiesecker, J.M., 2015. Mitigation for one $\&$ all: An integrated framework for mitigation of development impacts on biodiversity and ecosystem services. Environ. Impact Assess. Rev. 55, 21-34. doi:10.1016/j.eiar.2015.06.005

Tewolde, M.G., Cabral, P., 2011. Urban Sprawl Analysis and Modeling in Asmara, Eritrea. Remote Sens. 3, 2148-2165. doi:10.3390/rs3102148

Turner, R.K., Daily, G.C., 2008. The Ecosystem Services Framework and Natural Capital Conservation. Environ. Resour. Econ. 39, 25-35. doi:10.1007/s10640-007-9176-6

UN, D., 2014. World Urbanization Prospects The 2014 Revision, Highlights.

Vogl, A., Tallis, H., Douglass, J., Sharp, R., Wolny, S., Veiga, F., Benitez, S., León, J., Game, E., Petry, P., Guimerães, J., Lozano, J.S., 2015. Resource Investment Optimization System (RIOS). v1.1.0. Introduction and Theoretical Documentation. Stanford (CA).

Vrieling, A., Sterk, G., de Jong, S.M., 2010. Satellite-based estimation of rainfall erosivity for Africa. J. Hydrol. 395, 235-241. doi:10.1016/j.jhydrol.2010.10.035 


\section{SUPPLEMENTARY MATERIAL}

Part I: RIOS Approach, input data type, and analysis

This part shows how the RIOS and InVEST modules are integrated in the technical component of the approach for designing and assessing impact of WIs (Figure I).

For the RIOS module "Investment Portfolio Advisor", Part I also illustrates how the input data (see Table I) is actually analyzed to design the Investment Portfolios (Figure II). The main benefit of Part I is its usefulness for communicating with non-experts.

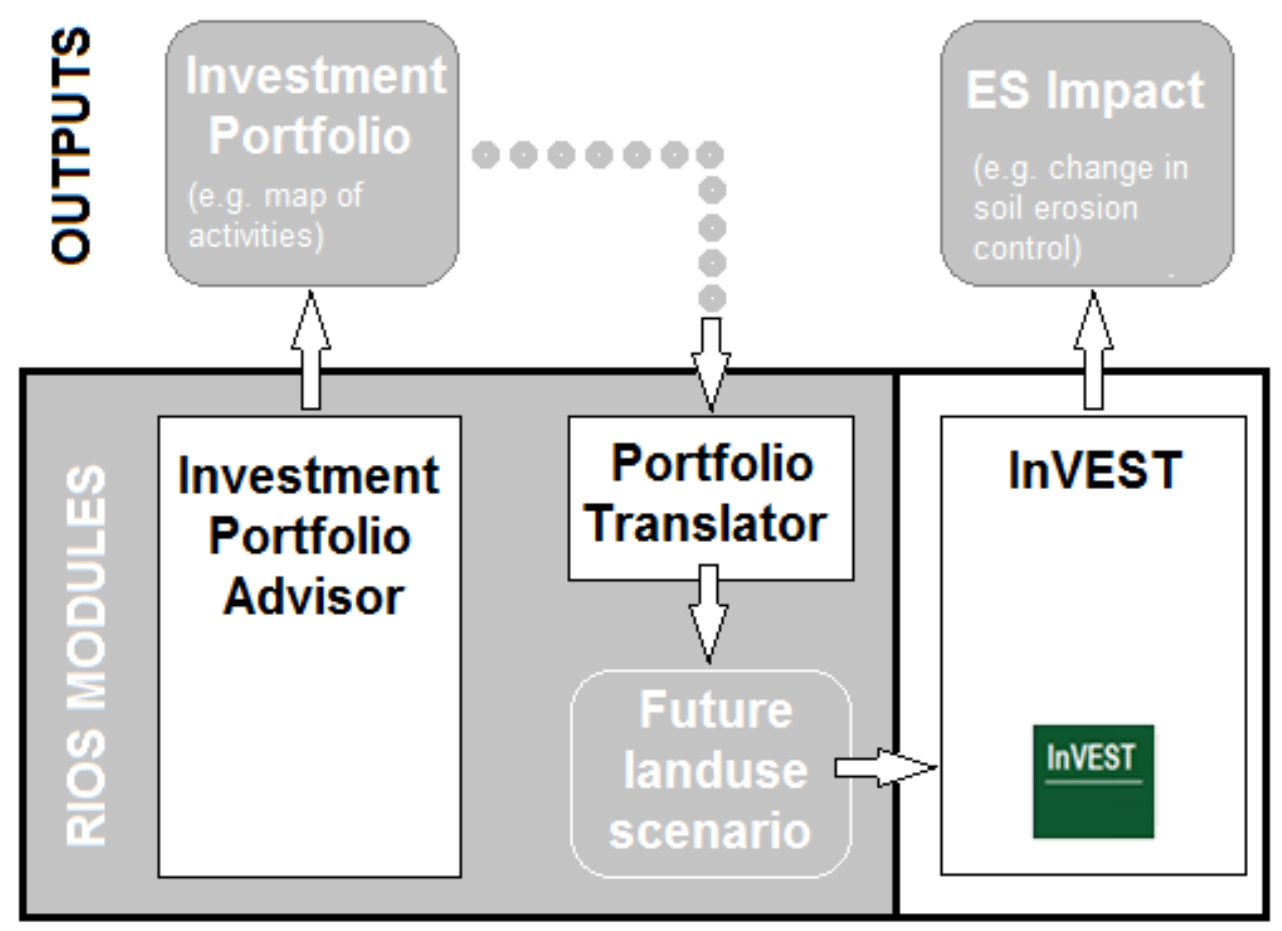

Figure I: Integration of RIOS and InVEST modules in the technical component of the proposed approach, as described in section 3.5 and 3.6(adapted from Vogl et al. 2015)

Table I: Description of the input data for the RIOS Module "Investment Portfolio Advisor"

\begin{tabular}{ll}
\hline & \\
\hline 1 & Land use / land cover map \\
2 & Table defining activities and indicating on which land cover types they are allowed \\
3 & Landscape factors influencing the effectiveness of transitions to achieve each objective \\
4 & The location and number of beneficiaries that benefit from activities in different areas \\
5 & Factor weights that describe the relative importance of each factor (and process); \\
6 & Objective weights that assign a relative weight when multiple objectives are considered \\
7 & Activity-Transition table indicating which user-defined activities cause which transitions \\
8 & Activity preference areas \\
9 & Floating budget and/or budgets by activity \\
10 & Activity costs \\
\hline
\end{tabular}




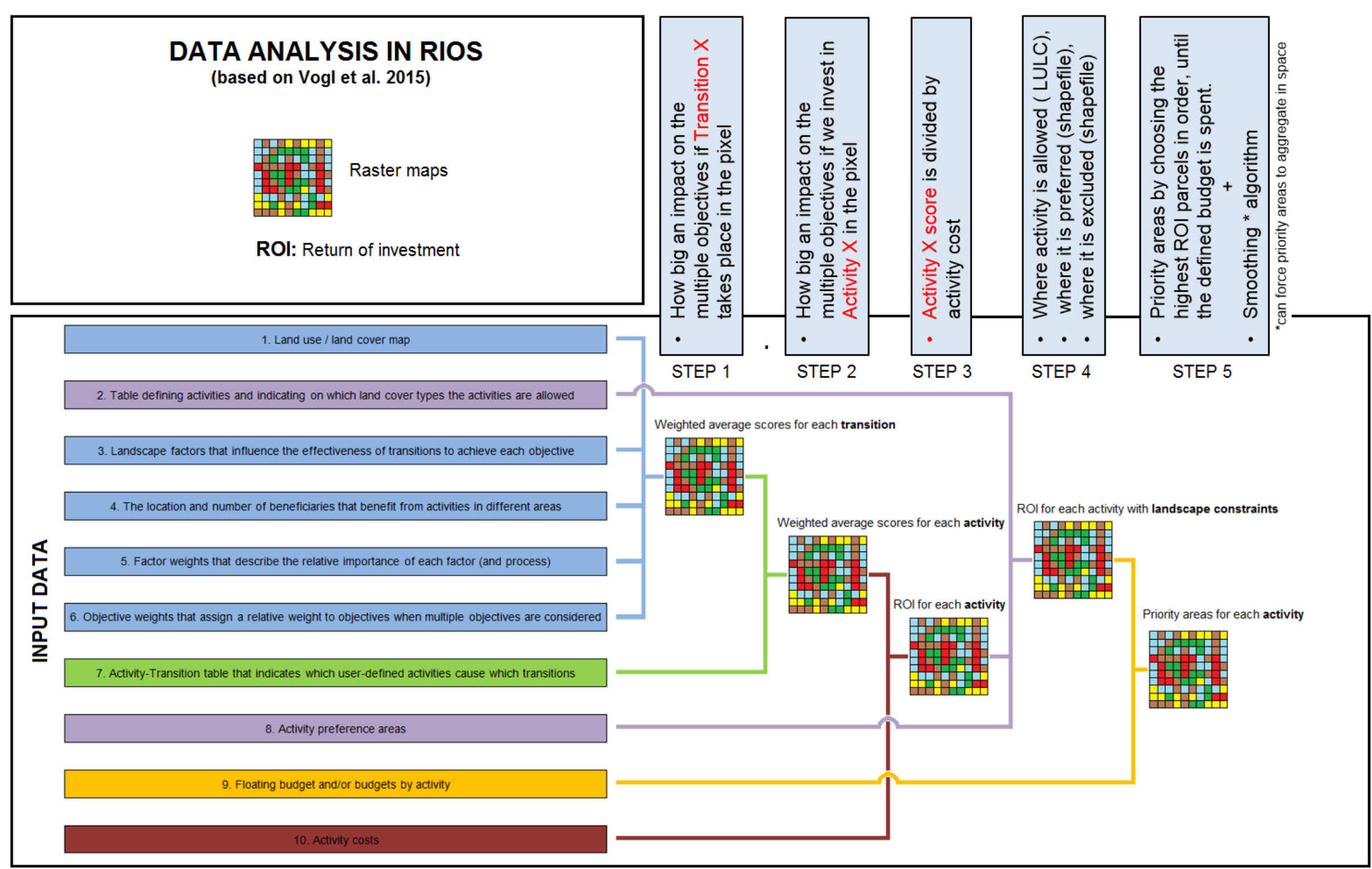

Figure II: Diagram showing how RIOS “Investment Portfolio Advisor” analyzes ten different input data types, to design WIs (based on Vogl et al. 2015) 


\section{Part II: Input data for RIOS}

Part II contains the main input data for application of the RIOS modules in the Toker Watershed case study. In the paper, these input data are described in section 3.5 and 3.6.

Table II RIOS “Investment Portfolio Advisor” Input - Defining transition potential and unit cost of activities.

\begin{tabular}{ccc}
\hline Activity & Transition & Unit cost (US\$/ha) \\
\hline Agricultural vegetation management & $\mathrm{D}$ & 125 \\
Protection & $\mathrm{A}$ & 125 \\
Restoration assisted & $\mathrm{C}$ & 1010 \\
Terracing & $\mathrm{E}$ & 310 \\
\hline
\end{tabular}

A - Keep native vegetation; B - Revegetation (unassisted); C - Revegetation (assisted); D - Agricultural vegetation management; E - Ditching; F- Fertilizer management; G - Pasture management

Table III: RIOS “Investment Portfolio Advisor” Input - Defining objective - transition weight of activities

\begin{tabular}{|c|c|c|c|c|c|c|c|}
\hline \multirow[t]{2}{*}{ Activity } & \multicolumn{7}{|c|}{ Transitions } \\
\hline & A & $\mathrm{B}$ & $\mathrm{C}$ & $\mathrm{D}$ & $\mathrm{E}$ & $\mathrm{F}$ & G \\
\hline Agricultural vegetation management & 0 & 0 & 0 & 1 & 0 & 0 & 0 \\
\hline Protection & 1 & 0 & 0 & 0 & 0 & 0 & 0 \\
\hline Restoration assisted & 0 & 0 & 1 & 0 & 0 & 0 & 0 \\
\hline Terracing & 0 & 0 & 0 & 0 & 1 & 0 & 0 \\
\hline
\end{tabular}

A - Keep native vegetation; B - Revegetation (unassisted); C - Revegetation (assisted); D - Agricultural vegetation management; E - Ditching; F- Fertilizer management; $\mathrm{G}$ - Pasture management

Table IV: RIOS “Investment Portfolio Advisor” Input - Restriction on activities based on landuse and slope

\begin{tabular}{ccccc}
\hline LULC & Agricultural vegetation management & Protection & Restoration & Terracing* \\
\hline Tropical mixed agriculture & Yes & - & Yes & Yes \\
Permanent crops & Yes & - & - & - \\
Mixed forest, agriculture & Yes & - & Yes & - \\
Tropical evergreen forest & - & - & Yes & - \\
Open water & - & - & - & - \\
Mixed urban & - & Yes & Yes & - \\
Floodplain forest & - & & & - \\
\hline
\end{tabular}

\footnotetext{
* No terracing for slope less than $12 \%$
} 
Table V: "RIOS Portfolio Translator" Input - Parameters for generating future land use scenario

\begin{tabular}{cccc}
\hline Old LULC & Transition Type & New LULC & PTF \\
\hline tropical mixed agriculture & Agricultural vegetation management & tropical corn & 0.65 \\
permanent crops & tropical corn & 0.65 \\
mixed forest, agriculture & " & mixed forest, agriculture, pasture & 0.65 \\
tropical evergreen forest & Protection (failed) & alfaalfa & 0.65 \\
floodplain forest & alfaalfa & 0.65 \\
tropical mixed agriculture & Revegetation (assisted) & conifer forest or woodland & 0.65 \\
tropical mixed agriculture & " & floodplain forest & 0.20 \\
mixed forest, agriculture & conifer forest or woodland & 0.65 \\
tropical mixed agriculture & Ditching & tropical corn & 0.65 \\
\hline
\end{tabular}

Table VI: Reclassification from the Africover landuse classes for Eritrea to the RIOS General landuse classes

\begin{tabular}{|c|c|}
\hline AFRICOVER: Land cover Database for Eritrea -User defined classes & $\begin{array}{l}\text { RIOS General landuse } \\
\text { classes }\end{array}$ \\
\hline $\begin{array}{c}\text { Closed semi-evergreen trees with closed to open shrubs + Rainfed Herbaceous Crop } \\
\text { agriculture }\end{array}$ & mixed forest, agriculture \\
\hline $\begin{array}{c}\text { Open shrubs with closed to open herbaceous and sparse trees + Rainfed Herbaceous Crop } \\
\text { agriculture }\end{array}$ & mixed forest, agriculture \\
\hline Forest plantation - Eucalyptus + Rainfed Herbaceous Crop, Small Fields, Clustered - Cereal" & mixed forest, agriculture \\
\hline Urban area & mixed urban \\
\hline Artificial lake & open water \\
\hline Irrigated Non-Graminoid Crop & permanent crops \\
\hline Sparse shrubs with sparse herbaceous & shrub/scrub \\
\hline tropical mixed agriculture & tropical mixed agriculture \\
\hline Bare soil + Rainfed Herbaceous Crop & tropical mixed agriculture \\
\hline $\begin{array}{c}\text { Rainfed Herbaceous Crop, Small Fields + Irrigated Non Graminoid Crop, Small Fields, } \\
\text { Clustered - Vegetables }\end{array}$ & tropical mixed agriculture \\
\hline Rainfed Herbaceous Crop, Small Fields - Cereal + Sparse trees with sparse herbaceous & tropical mixed agriculture \\
\hline Rainfed Herbaceous Crop, Small Fields - Cereal + Forest Plantation, Clustered - Eucalyptus & tropical mixed agriculture \\
\hline $\begin{array}{c}\text { Irrigated Non-Graminoid Crop, Small Fields - Vegetables + Forest Plantation, Clustered - } \\
\text { Eucalyptus }\end{array}$ & tropical mixed agriculture \\
\hline Rainfed Herbaceous Crop, Small Fields - Cereal + Bare soil & tropical mixed agriculture \\
\hline Forest plantation - Eucalyptus AND Artificial lake & floodplain forest \\
\hline Artificial lake AND Forest Plantation, Clustered - Eucalyptus & floodplain forest \\
\hline Forest plantation-Eucalyptus & tropical evergreen forest \\
\hline
\end{tabular}




\section{Part III: Additional results - Synthesis of investment portfolios and their performance}

Parts III contains results of the application of the technical component to the Toker Watershed case study. Three tables synthesize the 38 investment portfolios, 19 for each WI objective, and their respective performance.

The first two tables, for each scenario, specify the budget allocated to each activity as well as the areal extension covered by the activity (i.e. Investment portfolio).

The last table synthesizes the performance of each investment scenario in percentage reduction of soil erosion at sub-watershed level.

Table VII: Synthesis of investment portfolios for Urban Water Security - budget allocation and areal extension

\begin{tabular}{|c|c|c|c|c|c|c|c|c|c|c|c|}
\hline & & I & & I & & II & & & & $\mathbf{V}$ & \\
\hline \multirow{6}{*}{$\begin{array}{l}\stackrel{8}{8} \\
\dot{8} \\
\stackrel{\Delta}{\Delta}\end{array}$} & Activity & Budget & Area & Budget & Area & Budget & Area & Budget & Area & Budget & Area \\
\hline & Ag-mgmt & $\$ 56,846$ & 454.8 & $\$ 99,900$ & 799.2 & - & - & - & - & - & - \\
\hline & Protection & $\$ 43,054$ & 344.4 & - & - & $\$ 57,88$ & 463. & - & - & - & - \\
\hline & Restoratio & - & - & - & - & - & - & $\$ 99,990$ & 99.0 & - & - \\
\hline & Terracing & - & - & - & - & - & - & - & - & $\$ 99,882$ & 322.2 \\
\hline & Total & $\$ 99,900$ & 799.2 & $\$ 99,900$ & 799.2 & $\$ 57,88$ & 463. & $\$ 99,990$ & 99.0 & $\$ 99,882$ & 322.2 \\
\hline \multirow{5}{*}{ 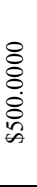 } & Ag-mgmt & $\$ 442,564$ & 3540.5 & $\$ 499,950$ & 3999.6 & & & - & - & - & - \\
\hline & Protection & $\$ 57,386$ & 459.1 & - & - & & & - & - & - & - \\
\hline & Restoratio & - & - & - & - & & & $\$ 499,950$ & 495.0 & - & - \\
\hline & Terracing & - & - & - & - & & & - & - & $\$ 499,968$ & 1612. \\
\hline & Total & $\$ 499,950$ & 3999.6 & $\$ 499,950$ & 3999.6 & & & $\$ 499,950$ & 495.0 & $\$ 499,968$ & 1612. \\
\hline \multirow{5}{*}{$\begin{array}{l}\stackrel{8}{8} \\
\dot{\leftrightarrow} \\
\dot{\Xi} \\
\dot{\infty}\end{array}$} & Ag-mgmt & $\$ 942,244$ & 7538.0 & $\$ 999,900$ & 7999.2 & & & - & - & - & - \\
\hline & Protection & $\$ 57,656$ & 461.3 & - & - & & & - & - & - & - \\
\hline & Restoratio & - & - & - & - & & & $\$ 999,900$ & 990.0 & - & - \\
\hline & Terracing & - & - & - & - & & & - & - & $\$ 999,936$ & 3225. \\
\hline & Total & $\$ 999,900$ & 7999.2 & $\$ 999,900$ & 7999.2 & & & $\$ 999,900$ & 990.0 & $\$ 999,936$ & 3225. \\
\hline \multirow{5}{*}{ 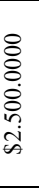 } & Ag-mgmt & $\$ 1,523,90$ & 12191. & $\$ 1,523,90$ & 12191. & & & - & - & - & - \\
\hline & Protection & $\$ 57,814$ & 462.5 & - & - & & & - & - & - & - \\
\hline & Restoratio & - & - & - & - & & & $\$ 2,499,75$ & 2475.0 & - & - \\
\hline & Terracing & - & - & - & - & & & - & - & $\$ 1,885,95$ & 6083. \\
\hline & Total & $\$ 1,581,71$ & 12653. & $\$ 1,523,90$ & 12191. & & & $\$ 2,499,75$ & 2475.0 & $\$ 1,885,95$ & 6083. \\
\hline \multirow{5}{*}{ 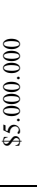 } & Ag-mgmt & & & & & & & - & - & & \\
\hline & Protection & & & & & & & - & - & & \\
\hline & Restoratio & & & & & & & $\$ 4,999,50$ & 4950.0 & & \\
\hline & Terracing & & & & & & & - & - & & \\
\hline & Total & & & & & & & $\$ 4,999,50$ & 4950.0 & & \\
\hline \multirow{5}{*}{ 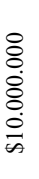 } & Ag-mgmt & & & & & & & - & - & & \\
\hline & Protection & & & & & & & - & - & & \\
\hline & Restoratio & & & & & & & $\$ 9,999,90$ & 9900.9 & & \\
\hline & Terracing & & & & & & & - & - & & \\
\hline & Total & & & & & & & $\$ 9,999,90$ & 9900.9 & & \\
\hline
\end{tabular}

Budget allocation modes:

- I Cost-effectiveness,

- II Only Agricultural vegetation management

- III Only Protection;

- IV Only Terracing;

- V Only Restoration assisted

Greyed boxes represent the 11 unfeasible scenarios (see Section 4.5).

Ag-mgmt stands for agricultural vegetation management. 
Table VIII: Synthesis of investment portfolios for Rural Poverty Alleviation - budget allocation and areal extension

\begin{tabular}{|c|c|c|c|c|c|c|c|c|c|c|c|}
\hline & & $\underline{I}$ & & I & & I & & & & V & \\
\hline \multirow{6}{*}{ 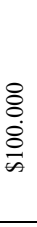 } & Activity & Budget & Area & Budget & Area & Budget & Area & Budget & Area & Budget & Area \\
\hline & Ag-mgmt & $\$ 83,711$ & 669.7 & $\$ 99,900$ & 799.2 & - & - & - & - & - & - \\
\hline & Protection & $\$ 16,189$ & 129.5 & - & - & $\$ 57,88$ & 463. & - & - & - & - \\
\hline & Restoratio & - & - & - & - & - & - & $\$ 99,990$ & 99.0 & - & - \\
\hline & Terracing & - & - & - & - & - & - & $\$ 0$ & 0.0 & $\$ 99,882$ & 322.2 \\
\hline & Total & $\$ 99,900$ & 799.2 & $\$ 99,900$ & 799.2 & $\$ 57,88$ & 463. & $\$ 99,990$ & 99.0 & $\$ 99,882$ & 322.2 \\
\hline \multirow{5}{*}{$\begin{array}{l}8 \\
8 \\
8 \\
\ddot{8} \\
\stackrel{0}{n} \\
n\end{array}$} & Ag-mgmt & $\$ 453,746$ & 3630.0 & $\$ 499,950$ & 3999.6 & & & - & - & - & - \\
\hline & Protection & $\$ 46,204$ & 369.6 & - & - & & & - & - & - & - \\
\hline & Restoratio & - & - & - & - & & & $\$ 499,950$ & 495.0 & - & - \\
\hline & Terracing & - & - & - & - & & & $\$ 0$ & 0.0 & $\$ 499,968$ & 1612. \\
\hline & Total & $\$ 499,950$ & 3999.6 & $\$ 499,950$ & 3999.6 & & & $\$ 499,950$ & 495.0 & $\$ 499,968$ & 1612. \\
\hline \multirow{5}{*}{$\begin{array}{l}8 \\
8 \\
\dot{8} \\
\dot{8} \\
\dot{\Delta}\end{array}$} & Ag-mgmt & $\$ 942,278$ & 7538.2 & $\$ 999,900$ & 7999.2 & & & - & - & - & - \\
\hline & Protection & $\$ 57,623$ & 461.0 & - & - & & & - & - & - & - \\
\hline & Restoratio & - & - & - & - & & & $\$ 999,900$ & 990.0 & - & - \\
\hline & Terracing & - & - & - & - & & & $\$ 0$ & 0.0 & $\$ 999,936$ & 3225 . \\
\hline & Total & $\$ 999,900$ & 7999.2 & $\$ 999,900$ & 7999.2 & & & $\$ 999,900$ & 990.0 & $\$ 999,936$ & 3225. \\
\hline \multirow{5}{*}{ 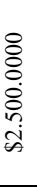 } & Ag-mgmt & $\$ 1,523,90$ & 12191. & $\$ 1,523,90$ & 12191. & & & - & - & - & - \\
\hline & Protection & $\$ 57,780$ & 462.2 & - & - & & & - & - & - & - \\
\hline & Restoratio & $\$ 545$ & 0.5 & - & - & & & $\$ 2,499,75$ & 2475.0 & - & - \\
\hline & Terracing & - & - & - & - & & & - & - & $\$ 1,885,95$ & 6083. \\
\hline & Total & $\$ 1,582,22$ & 12654. & $\$ 1,523,90$ & 12191. & & & $\$ 2,499,75$ & 2475.0 & $\$ 1,885,95$ & 6083. \\
\hline \multirow{5}{*}{$\begin{array}{l}8 \\
8 \\
\dot{8} \\
8 \\
\text { in }\end{array}$} & Ag-mgmt & & & & & & & - & - & & \\
\hline & Protection & & & & & & & - & - & & \\
\hline & Restoratio & & & & & & & $\$ 4,999,50$ & 4950.0 & & \\
\hline & Terracing & & & & & & & $\$ 0$ & 0.0 & & \\
\hline & Total & & & & & & & $\$ 4,999,50$ & 4950.0 & & \\
\hline \multirow{5}{*}{ 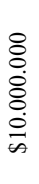 } & Ag-mgmt & & & & & & & - & - & & \\
\hline & Protection & & & & & & & - & - & & \\
\hline & Restoratio & & & & & & & $\$ 9,999,90$ & 9900.9 & & \\
\hline & Terracing & & & & & & & $\$ 0$ & 0.0 & & \\
\hline & Total & & & & & & & $\$ 9,999,90$ & 9900.9 & & \\
\hline
\end{tabular}

Budget allocation modes:

- I Cost-effectiveness,

- II Only Agricultural vegetation management

- III Only Protection;

- IV Only Terracing.

- V Only Restoration assisted

Greyed boxes represent the 11 unfeasible scenarios (see Section 4.5)

Ag-mgmt stands for agricultural vegetation management. 
Table IX: Synthesis of the performance of the 38 investment portfolios in the case study, expressed in percentage reduction of soil erosion at sub-watershed level

\begin{tabular}{|c|c|c|c|c|c|c|c|c|c|c|c|c|c|}
\hline & \multirow[b]{2}{*}{ ID } & \multicolumn{6}{|c|}{ URBAN WATER ECURITY } & \multicolumn{6}{|c|}{ RURAL POVERTY ALLEVIATION } \\
\hline & & $10 \mathrm{~K}$ & $\$ 50 \mathrm{~K}$ & $\$ 100 \mathrm{~K}$ & $\$ 250 \mathrm{~K}$ & $\$ 500 \mathrm{~K}$ & $\$ 1000 \mathrm{~K}$ & $10 \mathrm{~K}$ & $\$ 50 \mathrm{~K}$ & $\$ 100 \mathrm{~K}$ & $\$ 250 \mathrm{~K}$ & $\$ 500 \mathrm{~K}$ & $\$ 1000 \mathrm{~K}$ \\
\hline \multirow{8}{*}{ 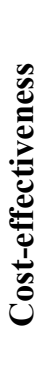 } & Toker & $-0.7 \%$ & $2.6 \%$ & $-10.1 \%$ & $-24.5 \%$ & & & $3.3 \%$ & $-6.1 \%$ & $-15.8 \%$ & $-24.5 \%$ & & \\
\hline & AdiSheka & $-5.5 \%$ & $-29.0 \%$ & $-29.6 \%$ & $-32.2 \%$ & & & $-0.3 \%$ & $-4.0 \%$ & $-17.4 \%$ & $-32.2 \%$ & & \\
\hline & Maisirwa & $-2.8 \%$ & $-8.7 \%$ & $-14.1 \%$ & $-28.6 \%$ & & & $-0.3 \%$ & $-5.3 \%$ & $-14.0 \%$ & $-28.6 \%$ & & \\
\hline & Beleza & $-2.3 \%$ & $-7.6 \%$ & $-18.9 \%$ & $-33.8 \%$ & & & $0.4 \%$ & $1.6 \%$ & $1.6 \%$ & $0.9 \%$ & & \\
\hline & Valle-Gnocchi & $0.0 \%$ & $-0.4 \%$ & $1.2 \%$ & $0.9 \%$ & & & $-1.6 \%$ & $-10.0 \%$ & $-24.3 \%$ & $-33.8 \%$ & & \\
\hline & AdiNifas_Do1 & $0.4 \%$ & $0.4 \%$ & $0.4 \%$ & $0.4 \%$ & & & $0.4 \%$ & $0.4 \%$ & $0.4 \%$ & $0.4 \%$ & & \\
\hline & AdiNifas_D02 & $0.0 \%$ & $4.9 \%$ & $5.0 \%$ & $5.0 \%$ & & & $5.0 \%$ & $5.0 \%$ & $5.0 \%$ & $5.0 \%$ & & \\
\hline & Total & $-2.2 \%$ & $-7.3 \%$ & $-15.3 \%$ & $-25.4 \%$ & & & $1.8 \%$ & $-5.0 \%$ & $-15.2 \%$ & $-25.4 \%$ & & \\
\hline \multirow{8}{*}{ 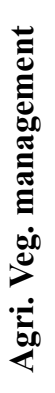 } & Toker & $-0.8 \%$ & $-2.6 \%$ & $-16.6 \%$ & $-29.6 \%$ & & & $-2.1 \%$ & $-12.4 \%$ & $-21.8 \%$ & $-29.6 \%$ & & \\
\hline & AdiSheka & $-8.3 \%$ & $-30.5 \%$ & $-31.1 \%$ & $-33.6 \%$ & & & $-1.6 \%$ & $-6.8 \%$ & $-20.3 \%$ & $-33.6 \%$ & & \\
\hline & Maisirwa & $-2.3 \%$ & $-8.9 \%$ & $-15.0 \%$ & $-28.6 \%$ & & & $-0.7 \%$ & $-6.2 \%$ & $-15.5 \%$ & $-28.6 \%$ & & \\
\hline & Beleza & $-2.7 \%$ & $-8.7 \%$ & $-20.5 \%$ & $-33.8 \%$ & & & $0.0 \%$ & $0.0 \%$ & $0.0 \%$ & $-0.7 \%$ & & \\
\hline & Valle-Gnocchi & $0.0 \%$ & $-0.4 \%$ & $-0.4 \%$ & $-0.7 \%$ & & & $-2.5 \%$ & $-11.9 \%$ & $-25.8 \%$ & $-33.8 \%$ & & \\
\hline & AdiNifas_Do1 & $0.0 \%$ & $0.0 \%$ & $0.0 \%$ & $0.0 \%$ & & & $0.0 \%$ & $0.0 \%$ & $0.0 \%$ & $0.0 \%$ & & \\
\hline & AdiNifas_D02 & $0.0 \%$ & $0.0 \%$ & $0.0 \%$ & $0.0 \%$ & & & $0.0 \%$ & $0.0 \%$ & $0.0 \%$ & $0.0 \%$ & & \\
\hline & Total & $-3.0 \%$ & $-10.9 \%$ & $-19.7 \%$ & $-28.8 \%$ & & & $-1.7 \%$ & $-9.7 \%$ & $-19.7 \%$ & $-28.8 \%$ & & \\
\hline \multirow{8}{*}{ 音 } & Toker & $5.0 \%$ & & & & & & $5.0 \%$ & & & & & \\
\hline & AdiSheka & $1.4 \%$ & & & & & & $1.4 \%$ & & & & & \\
\hline & Maisirwa & $0.0 \%$ & & & & & & $0.0 \%$ & & & & & \\
\hline & Beleza & $0.0 \%$ & & & & & & $1.6 \%$ & & & & & \\
\hline & Valle-Gnocchi & $1.6 \%$ & & & & & & $0.0 \%$ & & & & & \\
\hline & AdiNifas_Do1 & $0.4 \%$ & & & & & & $0.4 \%$ & & & & & \\
\hline & AdiNifas_D02 & $5.0 \%$ & & & & & & $5.0 \%$ & & & & & \\
\hline & Total & $3.4 \%$ & & & & & & $3.4 \%$ & & & & & \\
\hline \multirow{8}{*}{ 矛 } & Toker & $-0.1 \%$ & $-53.5 \%$ & $-58.9 \%$ & $-69.8 \%$ & $-75.7 \%$ & $-36.0 \%$ & $-0.4 \%$ & $-1.9 \%$ & $-4.1 \%$ & $-12.2 \%$ & $-23.8 \%$ & $-41.7 \%$ \\
\hline & AdiSheka & $-1.4 \%$ & $-89.8 \%$ & $-90.2 \%$ & $-90.8 \%$ & $-91.6 \%$ & $-53.8 \%$ & $-0.2 \%$ & $-2.2 \%$ & $-2.8 \%$ & $-5.6 \%$ & $-18.0 \%$ & $-44.9 \%$ \\
\hline & Maisirwa & $-0.2 \%$ & $1205.8 \%$ & $1197.0 \%$ & $1190.5 \%$ & $1104.2 \%$ & $-38.6 \%$ & $-0.1 \%$ & $-0.6 \%$ & $-2.1 \%$ & $-6.9 \%$ & $-17.8 \%$ & $-39.3 \%$ \\
\hline & Beleza & $-0.6 \%$ & $31.5 \%$ & $31.5 \%$ & $31.3 \%$ & $30.7 \%$ & $-0.6 \%$ & $0.0 \%$ & $0.0 \%$ & $0.0 \%$ & $0.0 \%$ & $0.0 \%$ & $-0.1 \%$ \\
\hline & Valle-Gnocchi & $0.0 \%$ & $-54.6 \%$ & $-54.6 \%$ & $-54.6 \%$ & $-54.6 \%$ & $-48.1 \%$ & $-1.1 \%$ & $-3.1 \%$ & $-5.5 \%$ & $-12.1 \%$ & $-26.3 \%$ & $-52.0 \%$ \\
\hline & AdiNifas_Do1 & $0.0 \%$ & $0.0 \%$ & $0.0 \%$ & $0.0 \%$ & $0.0 \%$ & $0.0 \%$ & $0.0 \%$ & $0.0 \%$ & $0.0 \%$ & $0.0 \%$ & $0.0 \%$ & $0.0 \%$ \\
\hline & AdiNifas_D02 & $0.0 \%$ & $132.8 \%$ & $123.2 \%$ & $105.7 \%$ & $87.1 \%$ & $0.0 \%$ & $0.0 \%$ & $0.0 \%$ & $0.0 \%$ & $0.0 \%$ & $0.0 \%$ & $0.0 \%$ \\
\hline & Total & $-0.5 \%$ & $-2.9 \%$ & $-6.6 \%$ & $-13.6 \%$ & $-21.4 \%$ & $-39.1 \%$ & $-0.3 \%$ & $-1.8 \%$ & $-3.4 \%$ & $-9.2 \%$ & $-20.3 \%$ & $-40.0 \%$ \\
\hline \multirow{8}{*}{ 包 } & Toker & $-0.4 \%$ & $-57.9 \%$ & $-59.1 \%$ & $-60.0 \%$ & & & $-0.9 \%$ & $-5.4 \%$ & $-9.3 \%$ & $-14.9 \%$ & & \\
\hline & AdiSheka & $-3.5 \%$ & $-90.1 \%$ & $-90.3 \%$ & $-91.1 \%$ & & & $-1.0 \%$ & $-3.0 \%$ & $-9.7 \%$ & $-20.4 \%$ & & \\
\hline & Maisirwa & $-1.4 \%$ & $1208.6 \%$ & $1145.7 \%$ & $1022.4 \%$ & & & $-0.2 \%$ & $-3.3 \%$ & $-6.7 \%$ & $-17.2 \%$ & & \\
\hline & Beleza & $-1.5 \%$ & $31.4 \%$ & $31.1 \%$ & $30.8 \%$ & & & $0.0 \%$ & $0.0 \%$ & $0.0 \%$ & $-0.5 \%$ & & \\
\hline & Valle-Gnocchi & $0.0 \%$ & $-54.6 \%$ & $-54.6 \%$ & $-54.6 \%$ & & & $-0.8 \%$ & $-3.5 \%$ & $-8.8 \%$ & $-14.7 \%$ & & \\
\hline & AdiNifas_Do1 & $0.0 \%$ & $0.0 \%$ & $0.0 \%$ & $0.0 \%$ & & & $0.0 \%$ & $0.0 \%$ & $0.0 \%$ & $0.0 \%$ & & \\
\hline & AdiNifas_D02 & $0.0 \%$ & $130.7 \%$ & $124.7 \%$ & $101.2 \%$ & & & $0.0 \%$ & $0.0 \%$ & $0.0 \%$ & $0.0 \%$ & & \\
\hline & Total & $-1.3 \%$ & $-5.4 \%$ & $-9.0 \%$ & $-15.5 \%$ & & & $-0.8 \%$ & $-4.2 \%$ & $-8.7 \%$ & $-15.5 \%$ & & \\
\hline
\end{tabular}

